\title{
Net ecosystem carbon exchange of a dry temperate eucalypt forest
}

\author{
Nina Hinko-Najera ${ }^{1}$, Peter Isaac ${ }^{2}$, Jason Beringer ${ }^{3}$, Eva van Gorsel $^{4}$, Cacilia Ewenz $^{5}$, Ian McHugh ${ }^{6}$, \\ Jean-François Exbrayat ${ }^{7}$, Stephen J. Livesley ${ }^{8}$, and Stefan K. Arndt ${ }^{8}$ \\ ${ }^{1}$ School of Ecosystem and Forest Sciences, The University of Melbourne, 4 Water Street, Creswick, VIC 3363, Australia \\ ${ }^{2}$ OzFlux Central Node, TERN-OzFlux, Melbourne, VIC 3159, Australia, Australia \\ ${ }^{3}$ School of Earth and Environment, The University of Western Australia, Crawley, WA, 6009, Australia \\ ${ }^{4}$ Fenner School of Environment and Society, The Australian National University, ACT, Canberra, Australia \\ ${ }^{5}$ Airborne Research Australia, Flinders University, Salisbury South, SA, 5106, Australia \\ ${ }^{6}$ School of Earth, Atmosphere and Environment, Monash University, Clayton, VIC 3800, Australia \\ ${ }^{7}$ School of GeoSciences and National Centre for Earth Observation, University of Edinburgh, Edinburgh, EH9 3FF, UK \\ ${ }^{8}$ School of Ecosystem and Forest Sciences, The University of Melbourne, 500 Yarra Boulevard, Richmond, \\ VIC 3121, Australia
}

Correspondence to: Nina Hinko-Najera (n.hinko.najera@gmail.com)

Received: 6 May 2016 - Discussion started: 13 May 2016

Revised: 26 May 2017 - Accepted: 14 July 2017 - Published: 23 August 2017

\begin{abstract}
Forest ecosystems play a crucial role in the global carbon cycle by sequestering a considerable fraction of anthropogenic $\mathrm{CO}_{2}$, thereby contributing to climate change mitigation. However, there is a gap in our understanding about the carbon dynamics of eucalypt (broadleaf evergreen) forests in temperate climates, which might differ from temperate evergreen coniferous or deciduous broadleaved forests given their fundamental differences in physiology, phenology and growth dynamics. To address this gap we undertook a 3-year study (2010-2012) of eddy covariance measurements in a dry temperate eucalypt forest in southeastern Australia. We determined the annual net carbon balance and investigated the temporal (seasonal and inter-annual) variability in and environmental controls of net ecosystem carbon exchange (NEE), gross primary productivity (GPP) and ecosystem respiration (ER). The forest was a large and constant carbon sink throughout the study period, even in winter, with an overall mean NEE of $-1234 \pm 109$ (SE) $\mathrm{g} \mathrm{C} \mathrm{m}^{-2} \mathrm{yr}^{-1}$. Estimated annual ER was similar for 2010 and 2011 but decreased in 2012 ranging from 1603 to $1346 \mathrm{~g} \mathrm{C} \mathrm{m}^{-2} \mathrm{yr}^{-1}$, whereas GPP showed no significant inter-annual variability, with a mean annual estimate of $2728 \pm 39 \mathrm{~g} \mathrm{C} \mathrm{m}^{-2} \mathrm{yr}^{-1}$. All ecosystem carbon fluxes had a pronounced seasonality, with GPP being greatest during spring and summer and ER being highest during summer, whereas peaks in NEE occurred in early spring and again in summer. High NEE in spring was
\end{abstract}

likely caused by a delayed increase in ER due to low temperatures. A strong seasonal pattern in environmental controls of daytime and night-time NEE was revealed. Daytime NEE was equally explained by incoming solar radiation and air temperature, whereas air temperature was the main environmental driver of night-time NEE. The forest experienced unusual above-average annual rainfall during the first 2 years of this 3-year period so that soil water content remained relatively high and the forest was not water limited. Our results show the potential of temperate eucalypt forests to sequester large amounts of carbon when not water limited. However, further studies using bottom-up approaches are needed to validate measurements from the eddy covariance flux tower and to account for a possible underestimation in ER due to advection fluxes.

\section{Introduction}

Terrestrial ecosystems, together with the ocean, take up more than half of the yearly anthropogenic $\mathrm{CO}_{2}$ emissions and their combined sink strength has increased over the past 5 decades in step with increased emissions (Ballantyne et al., 2012; Le Quéré et al., 2013, 2015). The terrestrial sink has been mostly attributed to the world's forest ecosystems over the last 2 decades (Le Quéré et al., 2013; Pan et al., 2011) 
and only recently has the importance of semi-arid ecosystems in the global carbon sink been identified (Ahlström et al., 2015; Poulter et al., 2014). Even so, forests play a crucial role in the global carbon cycle and climate change mitigation (IPCC, 2013; Pan et al., 2011).

Nonetheless, uncertainty remains regarding the future trend in and strength of this terrestrial carbon sink (Ciais et al., 2013; Mystakidis et al., 2016; Reichstein et al., 2013; Sitch et al., 2015). This is mainly related to the high interannual variability in the carbon uptake of ecosystems because of regional and even global variations in climate from year to year (Ahlström et al., 2015; Reichstein et al., 2013). The balance between gross primary productivity (GPP) and ecosystem respiration (ER) - the net ecosystem carbon exchange (NEE) - can be positive (a carbon sink) or negative (a carbon source), although other carbon exchanges such as dissolved organic transport and/or disturbance provide a true net ecosystem carbon balance (NECB) (Chapin et al., 2006). Hence, variability in NEE is dependent on variations in the component fluxes GPP and ER and their responses to climate and resource availability (Ahlström et al., 2015; Ciais et al., 2013; Reichstein et al., 2013). While some studies primarily attribute inter-annual variability in NEE to changes in respiration (Cox et al., 2000; Valentini et al., 2000), others point to a primary dependence on the variability in ecosystem GPP (Ahlström et al., 2015; Jung et al., 2011; Sitch et al., 2015).

Across various ecosystems the main environmental factors controlling GPP have been identified as being solar radiation, water vapour pressure deficit (VPD) and leaf area index (LAI), whereas temperature and soil moisture are the main environmental drivers of ER (Baldocchi, 2008; Beringer et al., 2016; Yi et al., 2010). Variability in NEE has also been demonstrated to be strongly influenced by variation in water availability (i.e. changes in rainfall). For instance, the overall effect of drought conditions has been shown to decrease NEE but it often varies which component, GPP or ER, drought conditions have the greatest impact on (Ciais et al., 2005; Reichstein et al., 2007; Schlesinger et al., 2015; Zhao and Running, 2010). It is therefore critical to assess the carbon balance of ecosystems to improve our knowledge of processes controlling NEE and their response to variability in environmental drivers and climate change. Another factor contributing to the uncertainty of future terrestrial carbon sinks is the still limited empirical data available on forest carbon dynamics to better constrain uncertainties of global and continental process-based carbon models and/or to improve data-driven model frameworks (Haverd et al., 2013a; Jung et al., 2011; Keenan et al., 2012; Roxburgh et al., 2004).

Forests in Australia occupy around 19\% of the continent and account for about $3 \%$ of forested area worldwide (ABARES, 2013), and until recently their potential contribution to the global carbon cycle had not been considered. The role of Australian ecosystems generally in the global carbon cycle has had recent attention in light of the strong 2011 La Niña event and global record terrestrial car- bon sink, in which Australian ecosystems, particularly semiarid ecosystems, played a major role in the continental and global carbon uptake anomaly (Haverd et al., 2013b, 2016; Poulter et al., 2014). Although semi-arid ecosystems have been suggested as dominant drivers in inter-annual variability and trends in the global net carbon sink (Ahlström et al., 2015), little is known about how Australian temperate eucalypt (broadleaved evergreen) forests may contribute to the global sink and inter-annual variability. Two-thirds of native forests in Australia are eucalypt forests ( $92 \mathrm{M} \mathrm{ha}$ ) and dry temperate eucalypt forests account for the largest proportion $(37 \%$ or $8.3 \mathrm{M} \mathrm{ha}$ ) of forest ecosystems in southeastern and southwestern Australia and are of high socio-economic value (ABARES, 2013). Growth and regeneration of temperate forests in the Northern Hemisphere are considered to account for the increasing global terrestrial carbon sink (Pan et al., 2011), although a recent study showed a decline in this trend (Sitch et al., 2015). While studies of the carbon balance in the Northern Hemisphere temperate forests are abundant, there are only a handful of studies that have been undertaken in temperate eucalypt forests in Australia and none of these were in dry temperate eucalypt forests (Beringer et al., 2016; Keith et al., 2009, 2012; Kilinc et al., 2012, 2013; Leuning et al., 2005; van Gorsel et al., 2013). The behaviour of temperate deciduous broadleaved or evergreen coniferous forests in the Northern Hemisphere cannot be presumed to be an analogue for temperate eucalypt forests. Apart from being broadleaf evergreen, with mostly sclerophyllous leaves, a key trait of eucalypt forests in Australia is the ability to rapidly and opportunistically respond to changing, either favourable or stressful, environmental conditions (Jacobs, 1955; Keith, 1997). This is an adaptation to disturbances such as fire or drought that are a major component of ecosystems on the Australian continent (ABARES, 2013; Beringer et al., 2015; Whitehead and Beadle, 2004). Moreover, Australian forests are generally water and nutrient limited and soils are highly weathered (Attiwill and Adams, 1993; Whitehead and Beadle, 2004). Keith et al. (2009) showed that a wet temperate eucalypt forest had a high carbon uptake capacity compared with other forests globally when not limited by water availability. No studies have been published on ecosystem carbon exchange in dry temperate eucalypt forests, where rainfall is considerably lower and soil moisture is likely to be a greater limiting factor.

The aim of this study was to assess the carbon uptake potential of a dry temperate eucalypt forest and to gain an understanding of its temporal carbon exchange dynamics and controls by using the eddy covariance (EC) technique (Baldocchi, 2008, 2003; Hutley et al., 2005) as part of the regional OzFlux network (Beringer et al., 2016).

Therefore, the objectives of our study were to (1) investigate seasonal and inter-annual variability in NEE, GPP and ER; (2) identify the environmental controls of these $\mathrm{CO}_{2}$ ecosystem fluxes on seasonal and inter-annual timescales; 
and (3) quantify annual estimates of NEE and its component fluxes in a dry temperate eucalypt forest.

\section{Materials and methods}

\subsection{Site description}

The Wombat State Forest OzFlux tower site (FLUXNET ID: AUS-Wom) is located in the Wombat State Forest, Victoria, about $120 \mathrm{~km}$ west of Melbourne, Australia $\left(37^{\circ} 25^{\prime} 20.5^{\prime \prime} \mathrm{S}\right.$, $\left.144^{\circ} 05^{\prime} 39.1^{\prime \prime} \mathrm{E}\right)$. The Wombat State Forest is classified as dry sclerophyll eucalypt forest or open (crown cover $>50-80 \%$ ) forest (ABARES, 2013) and is dominated by three broadleaved evergreen tree species: Eucalyptus obliqua (L'Hérit.), Eucalyptus rubida (Deane \& Maiden) and Eucalyptus radiata (Sieber ex DC). General forest history includes harvesting and patchy occurrences of bush fires. Selective harvesting occurred until early 1970 when it was replaced by a more intensive shelterwood (two-stage clear felling) system (Poynter, 2005). Since 2003, the Wombat State Forest has been under community forest management, a cooperative between the state government and the local community (Poynter, 2005), and harvesting has been strongly reduced. Forest management practices also include periodic low-fireintensity prescribed fires and firewood collection in designated areas.

The study site is a secondary regrowth forest (DSE, 2012), of mixed age, with an average canopy height of $22 \mathrm{~m}$ (Griebel et al., 2015), a basal area of $37 \mathrm{~m}^{2} \mathrm{ha}^{-1}$ (Moore, 2011) and an LAI of 1.8 (Griebel et al., 2016; Moore, 2011). The area was last selectively harvested in the early 1970s with the last bush fire on the outskirts of the study site recorded in 1982 and no recorded history of prescribed fires. The flux tower is located on a ridge at a mean altitude of $706 \mathrm{~m}$ a.s.l. and the terrain within the footprint is relatively level to the east of the tower, with gently sloping gullies $\left(<8^{\circ}\right)$ towards the southwest and northwest (Griebel et al., 2016). The understorey is sparse and dominated by austral bracken (Pteridium esculentum (G. Forst.) Cockayne), forest wire-grass (Tetrarrhena juncea $\mathrm{R}$. Br.), tussock grass (Poa sieberiana Sprengel), herbs (e.g. Gonocarpus tetragynus Labill., Viola hederacea Labill.) and rushes (Lomandra spp.) (Tolhurst, 2003). The climate is cool temperate to Mediterranean with wet, cold winters and dry, warm and hot summers. Long-term (20012013) mean annual air temperature was $12.1 \pm 0.1{ }^{\circ} \mathrm{C}$, with mean monthly maximum air temperatures of $26.3 \pm 0.5^{\circ} \mathrm{C}$ in January and mean minimum air temperatures of $3.2 \pm 0.1^{\circ} \mathrm{C}$ in July (nearest Bureau of Meteorology (BoM) station Ballarat, $28 \mathrm{~km} \mathrm{SW}$; Fig. 1a). The silty clay soil overlies clay derived from Ordovician marine sediments and is classified as acidic-mottled, dystrophic, yellow Dermosol (Robinson et al., 2003), which is moderate to highly weathered and exhibits low fertility. The long-term (1901-2014) mean annual rainfall at the nearest rainfall BoM station (Daylesford,
$11 \mathrm{~km} \mathrm{~N}$; Fig. 1b) is $879 \pm 18 \mathrm{~mm}$, with the highest rainfall occurring during winter and spring. For an overview and more detailed site characteristics, see Table 1.

\subsection{Instrumentation and data acquisition}

The guyed EC flux tower was established in January 2010 within a fenced compound. The micro-meteorological measurement system was installed at $30 \mathrm{~m}$ height and consisted of an open-path infrared gas analyser (IRGA; Li7500, LI-COR, Lincoln, USA) that measures $\mathrm{CO}_{2}$, water vapour concentrations, and atmospheric pressure and a 3-D sonic anemometer (CSAT3, Campbell Scientific Inc., Logan, USA) that measures turbulent wind vectors and virtual air temperature. Instantaneous measurements were carried out at $10 \mathrm{~Hz}$ and were stored on a CF (compact flash) card. Furthermore, calculated covariances with a $30 \mathrm{~min}$ averaging period were stored on a data logger (CR-3000, Campbell Scientific Inc., Logan, USA). Prior to the calculation of covariances at the end of a $30 \mathrm{~min}$ averaging period, $10 \mathrm{~Hz}$ data were filtered by the data logger depending on diagnostic information from both the sonic anemometer and IRGA in which data spikes were removed (Isaac et al., 2017). Concurrent measurements of environmental variables included air temperature $\left(T_{\mathrm{a}}\right)$ and absolute and relative humidity (HMP-45C probe, Vaisala, Finland) at 2 and $30 \mathrm{~m}$ height, incoming and reflected shortwave radiation and atmospheric and surface-emitted longwave radiation measured with a CNR1 net radiometer (Kipp and Zonen, Delft, the Netherlands) at $30 \mathrm{~m}$ height, rainfall measured with a tipping bucket rain gauge (CS702, Hydrological Services Pty Ltd., Sydney, Australia) at $1 \mathrm{~m}$ height, soil heat flux averaged over two sites at $8 \mathrm{~cm}$ depth (HFT3 plate, Campbell Scientific Inc., Logan, USA, and HFP01 plate, Hukseflux, Delft, the Netherlands), soil temperature $\left(T_{\mathrm{S}}\right)$ averaged over two sites at $10 \mathrm{~cm}$ depth (TCAV Thermocouple probes, Campbell Scientific Inc., Logan, USA), and volumetric soil water content (SWC) at $10 \mathrm{~cm}$ (averaged over two sites) and $50 \mathrm{~cm}$ depth (CS616 water content reflectometer probes, Campbell Scientific Inc., Logan, USA). All instrumentation was powered by a remote area power system consisting of a diesel generator and a $24 \mathrm{~V}$ battery bank inverter system (Powermaker Ranger 4.5, Eniquest, Australia). An automated remote connection using a GSM modem (GPRS/GSM Quadband Unimax router and Ethernet modem, Maxon Australia Pty Ltd., Padstow, Australia) provided real-time information on system status and ensured data acquisition on a daily basis. Additionally, data were stored on external $\mathrm{CF}$ cards, which were interchanged on a monthly basis. A footprint analysis by Griebel et al. (2016) using the parameterization of flux footprint predictions of Kljun et al. (2004) showed that the distribution of fluxes was relatively homogeneous and that the whole footprint consisted of the same forest type and dominant tree species and a roughly uniform basal area. For further details, see Griebel et al. (2016). 


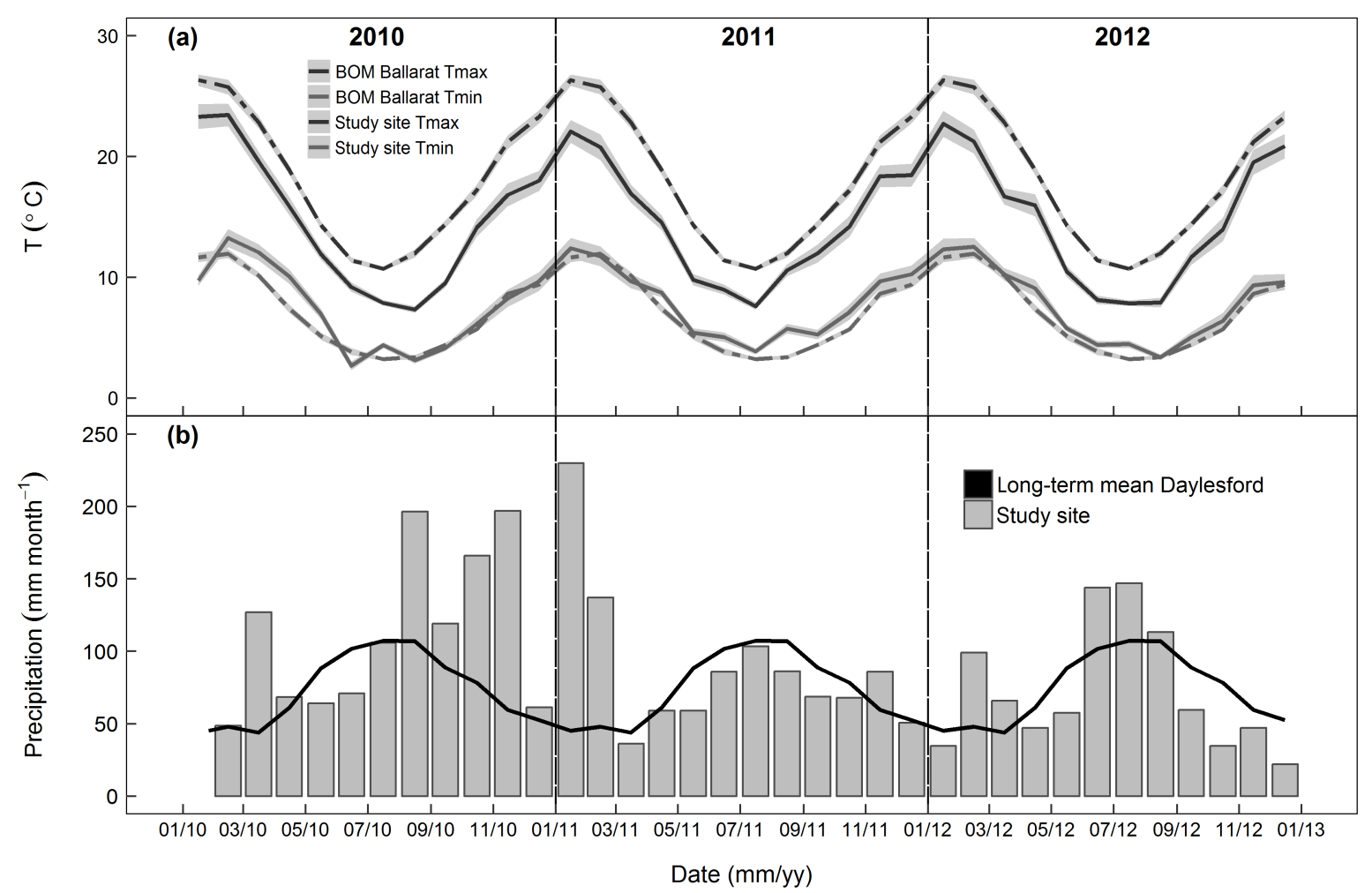

Figure 1. Climate time series of (a) monthly averages of minimum (grey lines) and maximum (black lines) air temperatures from the study site from 2010 to 2012 (solid lines) and from the BoM station Ballarat from 2001 to 2013 (dashed lines); shaded areas indicate \pm 1 SE. (b) Monthly rainfall at the Wombat State Forest OzFlux EC tower site from 2010 to 2012 (grey bars) and 114-year (1901-2014) long-term monthly mean rainfall at the BoM station Daylesford (black line).

Table 1. Site and tower characteristics for the Wombat State Forest OzFlux site.

\begin{tabular}{|c|c|}
\hline Location & $37^{\circ} 25^{\prime} \mathrm{S}, 144^{\circ} 05^{\prime} \mathrm{E}$ \\
\hline Elevation a.s.1. (m) & 706 \\
\hline Forest size (ha) & 70000 \\
\hline Tower height (m) & 30 \\
\hline Canopy height $(\mathrm{m})$ & $22^{\mathrm{b}}$ \\
\hline Canopy species & Eucalyptus obliqua, E. rubida, E. radiata \\
\hline Understorey species & Pteridium esculentum, Tetrarrhena juncea, Poa sieberiana, Lomandra spp. \\
\hline Mean annual air temperature $\left({ }^{\circ} \mathrm{C}\right)$ & $11.0 \pm 0.1$ \\
\hline Mean annual rainfall $(114 \text { years, } \mathrm{mm})^{\mathrm{a}}$ & $879 \pm 18$ \\
\hline LAI (leaf area index, $\mathrm{m}^{2} \mathrm{~m}^{-2}$ ) & $1.81^{\mathrm{c}}$ \\
\hline Tree density $\left(\mathrm{ha}^{-1}\right)$ & $1316^{\mathrm{c}}$ \\
\hline Tree $\mathrm{dbh}^{\mathrm{d}}(\mathrm{cm})$ & $18.6^{\mathrm{c}}$ \\
\hline Litterfall $\left(\mathrm{g} \mathrm{m}^{-2} \mathrm{yr}^{-1}\right)$ & $1120 \pm 52$ \\
\hline Soil type & acidic-mottled, dystrophic, yellow Dermosol \\
\hline Soil depth $(\mathrm{cm})$ & $50 \mathrm{~cm}$ \\
\hline $\mathrm{pH}$ & $4.83 \pm 0.02$ \\
\hline Bulk density $\left(0-10 \mathrm{~cm}, \mathrm{~kg} \mathrm{~m}^{-3}\right)$ & $0.94 \pm 0.02$ \\
\hline $\mathrm{C} / \mathrm{N}$ & $30.9 \pm 0.5$ \\
\hline Sand $(\%)$ & $45.4 \pm 1.8$ \\
\hline Silt $(\%)$ & $27.9 \pm 1.9$ \\
\hline Clay $(\%)$ & $26.7 \pm 0.4$ \\
\hline
\end{tabular}

Where applicable: mean of $n=3 \pm 1 \mathrm{SE} .{ }^{\text {a }}$ BoM station Daylesford, $11 \mathrm{~km} \mathrm{~N}$ of study site). ${ }^{\mathrm{b}}$ Griebel et al. (2015). ${ }^{\mathrm{c}}$ Moore (2011). ${ }^{\mathrm{d}}$ Dbh: diameter at breast height. 
In February 2012, a custom-built profile system including an IRGA (Li-840, LI-COR, Lincoln, USA) and six vertical layers $(1,2,4,8,15$ and $30 \mathrm{~m})$ was installed to measure $\mathrm{CO}_{2}$ concentrations of each layer in 2 min intervals (McHugh et al., 2017). A detailed description of the profile system can be found in McHugh et al. (2017). Due to technical problems with the IRGA profile, data were available from March to October 2012. Changes in the storage term between the forest floor and EC measurement point were calculated following McHugh et al. (2017) and Finnigan (2006). For periods of time when profile storage measurements were not available, ecosystem $\mathrm{CO}_{2}$ fluxes were accounted for by storage terms derived from single-point calculations within the OzFluxQC data processing (Isaac et al., 2017). However, the contribution of storage term only marginally changed the magnitude of NEE (on average $2 \%$ ) (Fig. S1 in the Supplement).

\subsection{Data processing}

\subsubsection{Quality control}

Quality assurance and quality control (QA-QC) and eddy covariance flux corrections were performed on both available $10 \mathrm{~Hz}$ data and $30 \mathrm{~min}$ covariance data. The $10 \mathrm{~Hz}$ data were processed with EddyPro version 6.2 (EddyPro, 2016), including default statistical analysis (spike removal, dropouts, absolute limits, skewness and/or kurtosis), lowand high-frequency correction (Massman, 2000; Moncrieff et al., 2005), and planar-fit coordinate rotation (Wilczak et al., 2001). The calculated covariances from the $30 \mathrm{~min}$ averaging period were processed following the OzFlux standard protocol and open source code OzFluxQC version 2.9.6e (Isaac et al., 2017, 2016) using Anaconda Python version 2.7 (Continuum Analytics, Texas, USA). The procedure is described in detail in its own method paper by Isaac et al. (2017), as well as by Eamus et al. (2013) and Cleverly et al. (2013). In brief, the OzFluxQC procedure included quality control checks such as range checks in plausible limits, spike detection, dependency checks and manual rejection of date ranges of all measured variables (covariances and environmental variables) depending on site characteristics and based on visual revision of the data during the $\mathrm{QA}-\mathrm{QC}$ procedure modified per month and year: linear corrections for calibration anomalies and sensor drift, 2-D coordinate rotation (Lee et al., 2005), Webb-Pearman-Leuning correction (Webb et al., 1980), low- and high-frequency correction according to Massman (2001, 2000) and Moncrieff et al. (2005), conversion of virtual heat flux to sensible heat flux and correction of ground heat flux for heat storage in the soil layer above, addition of single-point-calculated or profile-measurementderived storage term, and calculation of fluxes from the quality-controlled and corrected covariances. Extensive comparison between $10 \mathrm{~Hz}$ data processed with EddyPro and 30 min covariances processed with OzFluxQC showed that the planar-fit correction versus 2-D-coordinate rotation re- sulted in a $3 \%$ difference of fluxes. When this difference was accounted for in the OzFluxQC processed data set, both data sets were in very good agreement (slope: 1.01, intercept: $\left.0.06, R^{2}: 0.90\right)$. Periods of data with low turbulence conditions, predominantly during night-time, were excluded based on friction velocity $\left(u^{*}\right)$. Night-time $u^{*}$ was filtered with yearly determined $u^{*}$ thresholds using the change-point detection (CPD) method after Barr et al. (2013) and is described in detail in Isaac et al. (2017), Beringer et al. (2017) and McHugh et al. (2017), this issue. Uncertainty in the $u^{*}$ threshold was estimated by generating a probability distribution for the $u^{*}$ threshold and $95 \%$ confidence interval (CI) by bootstrapping the CPD method (1000 times randomly sampling of the data per year). Annual $u^{*}$ thresholds ranged from 0.53 to $0.66 \mathrm{~m} \mathrm{~s}^{-1}$. Data gaps occurred due to rainfall and occasional power failure and $60 \%$ of data were available over the 3-year period. Following QA-QC and night-time $u^{*}$ filtering, this was reduced to 37,49 and $49 \%$ in 2010, 2011 and 2012. From these values, quality-filtered data were $64 \%$ daytime data and $26 \%$ night-time data.

\subsubsection{Gap filling}

Subsequent gap filling of data was done either with the Dynamic INtegrated Gap-filling and partitioning for OzFlux (DINGO v13) routine (Beringer et al., 2017) or with the OzFluxQC procedure (Isaac et al., 2017), depending on the partitioning method selected (see below). However, both procedures have very similar data gap-filling procedures and are described in detail in Beringer et al. (2017) and Isaac et al. (2017). Small data gaps ( $\leq 2 \mathrm{~h}$ ) of continuous 30 min flux measurements and environmental variables were filled with linear interpolation.

In DINGO, data gaps of environmental variables (air temperature, humidity, radiation, wind speed, atmospheric pressure and rainfall) $>2 \mathrm{~h}$ were gap filled: (1) from linear regressions with AWS (automated weather station) 30 min data records from the three nearest BoM weather stations, which were ranked after best correlation and (2) with spatially gridded meteorological daily satellite data at $0.1^{\circ}$ resolution from the Australian Water Availability Project (AWAP; Raupach et al., 2009). In the unlikely event that gaps were still present after applying the methods above, then monthly diurnal means of measured climate variables were used. The frequency at which the correlation analysis between flux tower data and AWS was performed was set to use all available data. Soil temperature and soil moisture variables were gap filled using a simulation of the land surface using AWAP climate data and the CSIRO process-based land surface model BIOS2 at $0.05^{\circ}$ resolution (see Haverd et al., 2013a) adjusted to site observations. Following gap filling of environmental variables, half-hourly NEE data were gap filled using a feed forward artificial neural network (FFNET) with incoming shortwave solar radiation $\left(F_{\text {sd }}\right)$, vapour pressure deficit (VPD), SWC, $T_{\mathrm{s}}$, wind speed (WS) and enhanced vegetation index (EVI) 
as input drivers according to Beringer et al. $(2007,2017)$ and Papale and Valentini (2003). EVI was obtained from 16day compositing periods from MODIS (Moderate Resolution Imaging Spectroradiometer; see Huete et al., 2002) as surrogate information of vegetation activity (i.e. LAI and growth) and interpolated to $30 \mathrm{~min}$ as a proxy for production related to plant respiration. Frequency of gap filling using a neural network (NN) was set to all available data.

In OzFluxQC, data gaps of environmental variables $>2 \mathrm{~h}$ were gap filled: (1) with AWS as in DINGO, (2) using the regional Australian Community Climate Earth System 5 Simulator (ACCESS-R) numerical weather prediction (NWP) model at a resolution of $12.5 \mathrm{~km}$ run by the BoM (Isaac et al., 2017) and (3) ERA-Interim (ERAI) data set from the European Centre for Medium Range Weather Forecasting (Dee et al., 2011) at $75 \mathrm{~km}$ resolution across Australia. Half-hourly NEE data were gap filled using the SOLO NN (Abramowitz, 2005; Hsu et al., 2002) with net radiation $\left(F_{\mathrm{n}}\right)$, ground heat flux $\left(F_{\mathrm{g}}\right)$, specific humidity $(q)$, VPD, SWC, $T_{\mathrm{a}}$ and $T_{\mathrm{S}}$ as input drivers according to Isaac et al. (2017).

\subsubsection{Partitioning and carbon flux definitions}

The partitioning of NEE into its component fluxes GPP and ER was following the assumption of

$\mathrm{NEE}=\mathrm{ER}-\mathrm{GPP}$,

in which daytime NEE is the difference of GPP and ER, and night-time NEE is equal to ER. Hence, GPP is negligible or zero. We adopt the conventions in Chapin et al. (2006) in which GPP and ER fluxes are designated with a positive sign. Negative NEE fluxes denote a net carbon flux from the atmosphere to the ecosystem and thus a net carbon uptake by the forest ecosystem.

One of the most common uncertainties in EC measurements can be an underestimation of night-time NEE or ER as turbulent mixing is often lower or absent at night-time, which can lead to undetectable vertical and horizontal advection of $\mathrm{CO}_{2}$ within the canopy (Aubinet et al., 2012; Baldocchi, 2003; Goulden et al., 1996; van Gorsel et al., 2007). Although $u^{*}$ filtering is the most common correction for this underestimation error (Goulden et al., 1996), many studies have reported smaller estimates of ER from $u^{*}$-filtered and gap-filled EC tower data compared to those from chamber measurements of soil, leaf and stem respiration (Keith et al., 2009; Lavigne et al., 1997; Law et al., 1999; Phillips et al., 2010; Speckman et al., 2015). Although no independent upscaled ER estimates from chamber measurements were available from our study site, we used independent daily soil respiration data from a separate study at the same study site (Hinko-Najera, 2016, unpublished data) to visually compare its relative contribution to daily tower ER estimates derived from four different data selection and subsequent partitioning methods to reduce a potential underestimation of ER (see Supplement Figs. S1, S2 and
S3). We ran an ensemble of different partitioning methods (using either DINGO or OzFluxQC routines) and $u^{*}$-based night-time filters on NEE fluxes, including only the storage term, to evaluate variation in ecosystem carbon fluxes depending on the partitioning and filter method used. An overview of partitioning methods, estimated annual sums and their variation is given in the Supplement in Tables S1, S2 and Fig. S4 and briefly explained here. We used three different partitioning methods to estimate gross ecosystem carbon fluxes: (1) the night-time approach after the Lloyd and Taylor temperature-response function (Lloyd and Taylor, 1994; Reichstein et al., 2005) with $T_{\mathrm{a}}$ as the input driver using a window size of 15 days with an overlapping of 10 days in OzFluxQC; (2) night-time approach using the NN: (2a) FFNET with $T_{\mathrm{s}}, T_{\mathrm{a}}$, SWC and EVI as input drivers and a window size of all available data in DINGO (Beringer et al., 2017) or (2b) SOLO NN with $T_{\mathrm{a}}, T_{\mathrm{S}}$ and SWC as input drives and a window size of 1 year in OzFluxQC (2b) (Isaac et al., 2017); and (3) the daytime approach using the light-response function according to Lasslop et al. (2010) using either (3a) DINGO or (3b) OzFluxQC with a window size of 15 days with an overlapping of 10 days. Detailed descriptions of functions and routines used within the DINGO and OzFluxQC routines are given in Beringer et al. (2017) and Isaac et al. (2017). For the methods using the night-time approach, the $u^{*}$ filter after the $u^{*}$ threshold was applied to non-gap-filled (quality-controlled observations only) nighttime $\left(F_{\mathrm{sd}}<10 \mathrm{~W} \mathrm{~m}^{-2}\right)$ NEE flux data. The differences between DINGO (2a) and OzFluxQC $(1,2 b)$ partitioning methods here is that DINGO was set to use $u^{*}$-filtered night-time data from the first 3 hours after sunset only $\left(F_{\text {sd }}<10 \mathrm{~W} \mathrm{~m}^{-2}\right)$ while with OzFluxQC three night-time selections have been applied to $u^{*}$-filtered night-time data: all $u^{*}$ filtered nighttime NEE data, first three hours after sunset of $u^{*}$ filtered NEE data, and a variable daily window size using all nighttime data above the $u^{*}$ threshold from sunset onwards until $u^{*}$ fall below the $u^{*}$ threshold (Eva van Gorsel, personal communication). The selection of the first 3 hours after sunset is based on an extensive study in a wet temperate eucalypt forest from van Gorsel et al. (2008, 2007), who demonstrated that ER was at a maximum in the early evening hours when the canopy is still coupled with the atmosphere. For the NN methods (2a) and (2b), estimated night-time ER was extrapolated to daytime ER. The final NEE flux was then constructed from gap-filled daytime data $\left(F_{\mathrm{sd}} \geq 10 \mathrm{~W} \mathrm{~m}^{-2}\right)$ and estimated ER at night-time. GPP was then subsequently estimated with Eq. (1). For the methods using the daytime approach, a light-response curve (LRC) was fitted to daytime NEE to estimate GPP and subsequently ER across day and night. 


\subsection{Uncertainty analysis and analysis of environmental drivers}

We performed an uncertainty analysis as described in McHugh et al. (2017), which includes an uncertainty estimation of combined random and model error (Hollinger and Richardson, 2005; Keith et al., 2009) (Supplement Table S3) and the effect of uncertainties in $u^{*}$ thresholds on annual NEE estimates by using the lower (5\%) and upper $(95 \%)$ confidence interval of the probability distribution of the mean $u^{*}$ threshold (Barr et al., 2013) (Supplement Table S4). The uncertainty introduced due to random (measurement) and model error was small for 2010 and 2012 (4 and $6 \%$ of annual NEE estimate) and slightly higher for 2011 ( $10 \%$ of annual NEE estimate) (Table S3). Estimations of the uncertainties in $u^{*}$ thresholds on annual NEE were small for the lower $u^{*}$ uncertainty bound $(5 \% \mathrm{CI})$, ranging from $-19 \mathrm{~g} \mathrm{C} \mathrm{m}^{-2} \mathrm{yr}^{-1}$ in 2012 to $26 \mathrm{~g} \mathrm{C} \mathrm{m}^{-2} \mathrm{yr}^{-1}$ in $2011(1-$ $2 \%$ of annual NEE estimate). We could not estimate an upper $u^{*}$ uncertainty bound $(95 \% \mathrm{CI})$ as data availability was insufficient (Table S4).

To analyse environmental controls $\left(F_{\mathrm{sd}}, T_{\mathrm{a}}\right.$, VPD and SWC) on the seasonal and inter-annual variability in daytime NEE, a rectangular hyperbolic LRC or Michaelis-Menten equation (Carrara et al., 2004; Falge et al., 2001; Flanagan et al., 2002; Lasslop et al., 2010; Michaelis and Menten, 1913) was used to determine the dependency of daily means of quality controlled half-hourly non-gap-filled midday NEE (hours 11:00-13:00 AEST) on $F_{\text {sd }}$ :

$\mathrm{NEE}_{\text {midday }}=\frac{\alpha \times F_{\mathrm{sd}} \times \beta}{\alpha \times F_{\mathrm{sd}}+\beta}$,

in which $F_{\text {sd }}$ is the incoming solar radiation $\left(\mathrm{W} \mathrm{m}^{-2}\right), \alpha$ is the slope of LRC or the canopy light utilization efficiency $\left(\mu \mathrm{mol} \mathrm{CO} \mathrm{J}^{-1}\right.$ ) and $\beta$ is the maximum NEE or uptake rate of the canopy at light saturation $\left(\mu \mathrm{mol} \mathrm{CO} \mathrm{CO}^{-2} \mathrm{~s}^{-1}\right)$. Residuals of the LRC were then used to analyse the dependency of midday NEE on either $T_{\mathrm{a}}$ or VPD (given the strong correlation between VPD on $T_{\mathrm{a}}$ ) (Carrara et al., 2004; Chen et al., 2002) with linear and non-linear regressions, i.e. exponential temperature sensitivity functions according to Lloyd and Taylor (1994) for $T_{\mathrm{a}}$ (see Eq. 3 below) and a logarithmic power model according to Chen et al. (2002) for VPD. However, for both $T_{\mathrm{a}}$ and VPD, linear relationships resulted in the best fits, whereas non-linear regressions consistently resulted in arbitrary or insignificant parameter estimates. The influence of SWC on daytime NEE was tested with linear regressions between SWC and residuals of LRC. Second residuals from the linear relationships between LRC residuals and $T_{\mathrm{a}}$ as temperature and soil moisture are often negatively correlated in this forest ecosystem (Hinko-Najera et al., 2015). To analyse the effect of $T_{\mathrm{a}}$, VPD and SWC on LRC, data were divided into $T_{\mathrm{a}}$, VPD and SWC bins.

For the analysis of environmental controls $\left(T_{\mathrm{a}}, \mathrm{SWC}\right)$ on the seasonal and inter-annual variability in night-time NEE, an Arrhenius-type model function (LT) according to Lloyd and Taylor (1994) was applied to determine the temperature sensitivity of daily means of half-hourly quality-controlled non-gap-filled and $u^{*}$-filtered night-time NEE:

$\mathrm{NEE}_{\mathrm{NT}}=R_{\mathrm{ref}} \times \exp \left(E \times\left(\frac{1}{T_{\mathrm{ref}}-T_{0}}-\frac{1}{T_{\mathrm{a}}-T_{0}}\right)\right)$,

in which $R_{\text {ref }}$ is the basal respiration rate $\left(\mu \mathrm{mol} \mathrm{CO} \mathrm{CO}^{-2} \mathrm{~s}^{-1}\right)$ at the reference air temperature of $10^{\circ} \mathrm{C}\left(T_{\text {ref }}=283.15 \mathrm{~K}\right), E$ the activation energy parameter, $T_{0}$ a fixed temperature parameter $\left(T_{0}=227.13 \mathrm{~K}\right)$ according to Lloyd and Taylor (1994), and $T_{\mathrm{a}}$ the air temperature (K). Residuals of LT were then used to analyse the dependency of night-time NEE on SWC with linear regressions. To analyse the effect of SWC on LT, data were divided into SWC bins.

All subsequent data manipulation and statistical analyses were done using $\mathrm{R}$ version 3.3.2 (R Core Team, 2016), and for gap-filled times series we chose the night-time partitioning approach from the DINGO output. Differences in seasonal and inter-annual variations in daily means were tested with the Kruskal-Wallis rank sum test and Dunn's test.

\section{Results}

\subsection{Seasonal and inter-annual variation in environmental variables}

Seasonal and inter-annual patterns in rainfall varied markedly across the 3-year period (Figs. 1b, 2f). In the first 2 years unusually high rainfall was observed during the occurrence of two strong La Niña events. Annual rainfall in 2010 and 2011 was 43 and $22 \%$ above the long-term mean annual rainfall from the nearest BoM station (Daylesford), which is representative for the study site as an adjustment was less than $1 \%$ (Tables 1,2). Most of the anomalous rainfall occurred between August 2010 and February 2011, with a 2-fold increase in rainfall during spring 2010 (SON) and a 3 -fold increase in rainfall in summer 2010/11 (DJF, Fig. 1b). While the annual rainfall in 2012 was close to the long-term mean annual rainfall (Tables 1,2), monthly rainfall showed a distinct pattern with the long-term mean rainfall in February 2012 (2-fold increase) above and winter 2012 (JJA, +30\%) but below long-term mean rainfall from spring 2012 (SON, $-37 \%$ ) onwards (Figs. 1b, 2f).

SWC at $10 \mathrm{~cm}$ soil depth generally varied strongly with seasons and was highest during winter, with a daily maximum of $0.36 \mathrm{~cm}^{3} \mathrm{~cm}^{-3}$ observed in August 2012, and decreased towards summer, reaching a daily minimum of $0.12 \mathrm{~cm}^{3} \mathrm{~cm}^{-3}$ in February 2012 (Fig. 2e). Seasonal variability in SWC was more pronounced in $2012(\mathrm{CV}=25 \%)$ than in $2010(\mathrm{CV}=18 \%)$ as high rainfall led to an absence of a dry period during summer 2010/11 (DJF) and SWC remained relatively stable and high throughout $2011(\mathrm{CV}=13 \%)$. 

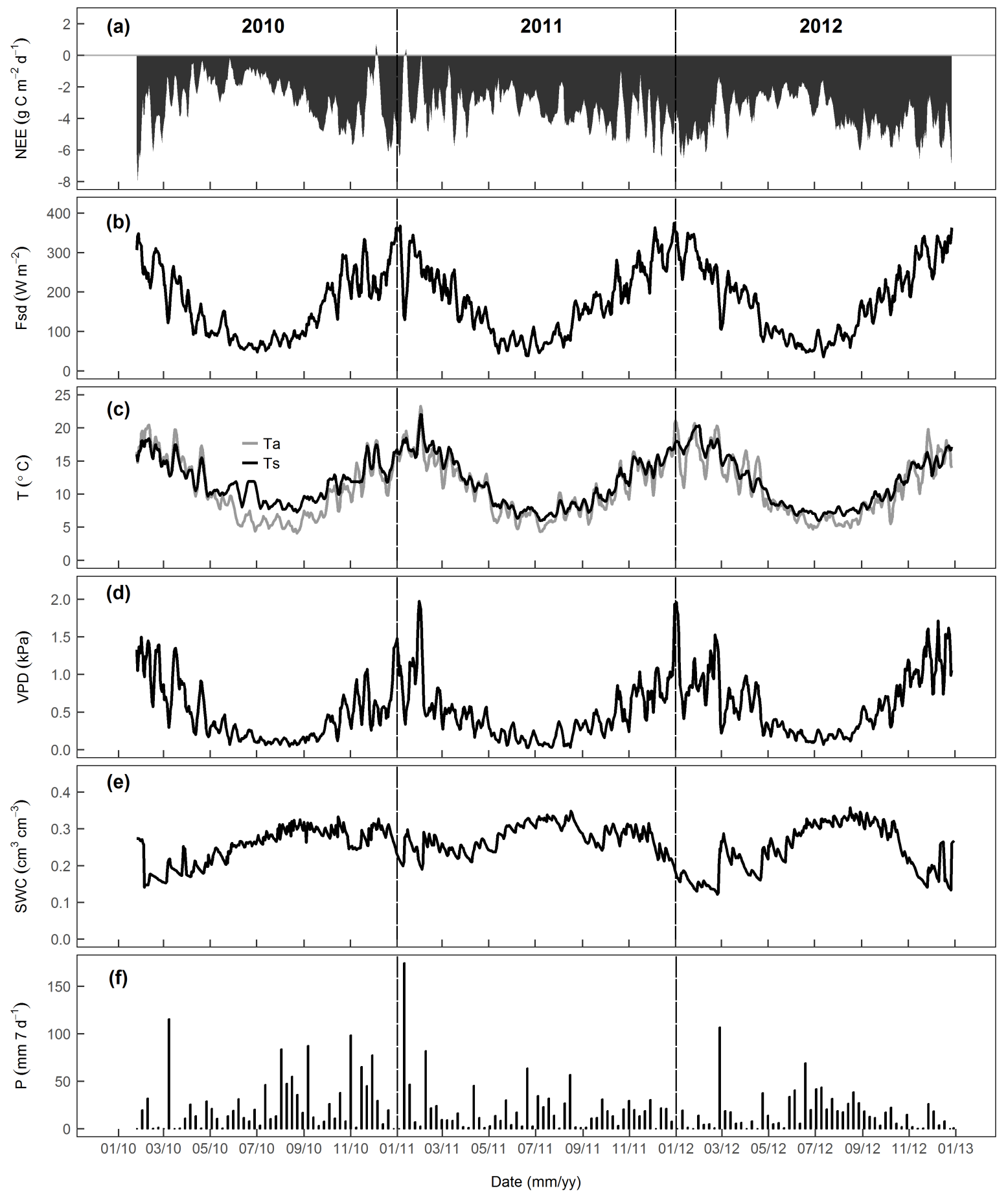

Figure 2. Time series of (a) 7-day running means of daily total net ecosystem exchange (NEE), 7-day running means of daily averages of (b) incoming solar radiation $\left(F_{\mathrm{sd}}\right),(\mathbf{c})$ air $\left(T_{\mathrm{a}}\right)$ and soil $\left(T_{\mathrm{S}}\right)$ temperature, and (d) 7-day running means of mean midday (11:00-13:00 AEST) vapour pressure deficit (VPD), (e) daily averages of volumetric soil water content (SWC), and (f) 7-day sums of rainfall $(P)$ from 2010 to 2012.

$F_{\mathrm{sd}}, T_{\mathrm{a}}, T_{\mathrm{S}}$ and VPD showed a strong seasonality, with maximum values during summer months and minimum values during winter months (Fig. 2b, c, d). Mean daily $F_{\text {sd }}$ was $278 \mathrm{~W} \mathrm{~m}^{-2}$ in summer (maximum of $411 \mathrm{~W} \mathrm{~m}^{-2}$ in Jan- uary 2011) and $81 \mathrm{~W} \mathrm{~m}^{-2}$ in winter (minimum of $5 \mathrm{~W} \mathrm{~m}^{-2}$ in May 2011; Fig 2b). Daily mean temperatures ranged from $2.0^{\circ} \mathrm{C}$ in winter (JJA) to $28.2{ }^{\circ} \mathrm{C}$ in summer (DJF) for $T_{\mathrm{a}}$ and from 4.8 to $23.6^{\circ} \mathrm{C}$ for $T_{\mathrm{S}}$ (Fig. 2c). A daily maxi- 
Table 2. Annual averages of incoming solar radiation $\left(F_{\mathrm{sd}}\right)$, air temperature $\left(T_{\mathrm{a}}\right)$, soil temperature $\left(T_{\mathrm{S}}\right)$, soil water content (SWC), vapour pressure deficit (VPD), annual sums of rainfall $(P)$, net ecosystem exchange (NEE), ecosystem respiration (ER) and gross primary productivity (GPP) at Wombat State Forest from 2010 to 2012; CV - coefficient of variation for inter-annual variation; inter-annual differences are indicated with $^{* * *}(p<0.001),{ }^{* *}(p<0.01)$ or ns (not significant). Letters indicate year-to-year differences.

\begin{tabular}{lccccccccc}
\hline Year & $\begin{array}{c}F_{\mathrm{Sd}} \\
\left(\mathrm{W} \mathrm{m}^{-2}\right)\end{array}$ & $\begin{array}{c}T_{\mathrm{a}} \\
\left({ }^{\circ} \mathrm{C}\right)\end{array}$ & $\begin{array}{c}T_{\mathrm{S}} \\
\left({ }^{\circ} \mathrm{C}\right)\end{array}$ & $\begin{array}{c}\mathrm{SWC} \\
(v / v)\end{array}$ & $\begin{array}{c}\mathrm{VPD} \\
(\mathrm{kPa})\end{array}$ & $\begin{array}{c}P \\
(\mathrm{~mm})\end{array}$ & $\begin{array}{c}\mathrm{NEE} \\
\left(\mathrm{g} \mathrm{C} \mathrm{m}^{-2}\right)\end{array}$ & $\begin{array}{c}\mathrm{ER} \\
\left(\mathrm{g} \mathrm{C} \mathrm{m}^{-2}\right)\end{array}$ & $\begin{array}{c}\mathrm{GPP} \\
\left(\mathrm{g} \mathrm{C} \mathrm{m}^{-2}\right)\end{array}$ \\
\hline $2010^{*}$ & 174 & 11.0 & 12.1 & $0.25 a$ & $0.36 a$ & 1254 & $-1046 a$ & $1603 a$ & 2649 \\
2011 & 177 & 11.1 & 11.8 & $0.27 b$ & $0.32 a$ & 1070 & $-1231 b$ & $1534 a$ & 2764 \\
2012 & 182 & 11.1 & 11.8 & $0.24 a$ & $0.47 b$ & 872 & $-1424 c$ & $1346 b$ & 2770 \\
\hline $\mathrm{CV}(\%)$ & $2.5 \mathrm{~ns}$ & $0.5 \mathrm{~ns}$ & $1.2 \mathrm{~ns}$ & $6.6^{* * *}$ & $20.0^{* * *}$ & 17.9 & $15.3^{* * *}$ & $8.9^{* * *}$ & $2.5 \mathrm{~ns}$ \\
\hline
\end{tabular}

* Includes extrapolated values until 21 January; estimates without extrapolation, i.e. 344 days: $P(\mathrm{~mm}): 1229, \mathrm{NEE}\left(\mathrm{g} \mathrm{C} \mathrm{m}^{-2}\right):-958, \mathrm{ER}$ $\left(\mathrm{g} \mathrm{C} \mathrm{m}^{-2}\right): 1476, \mathrm{GPP}\left(\mathrm{g} \mathrm{C} \mathrm{m}^{-2}\right): 2434$.

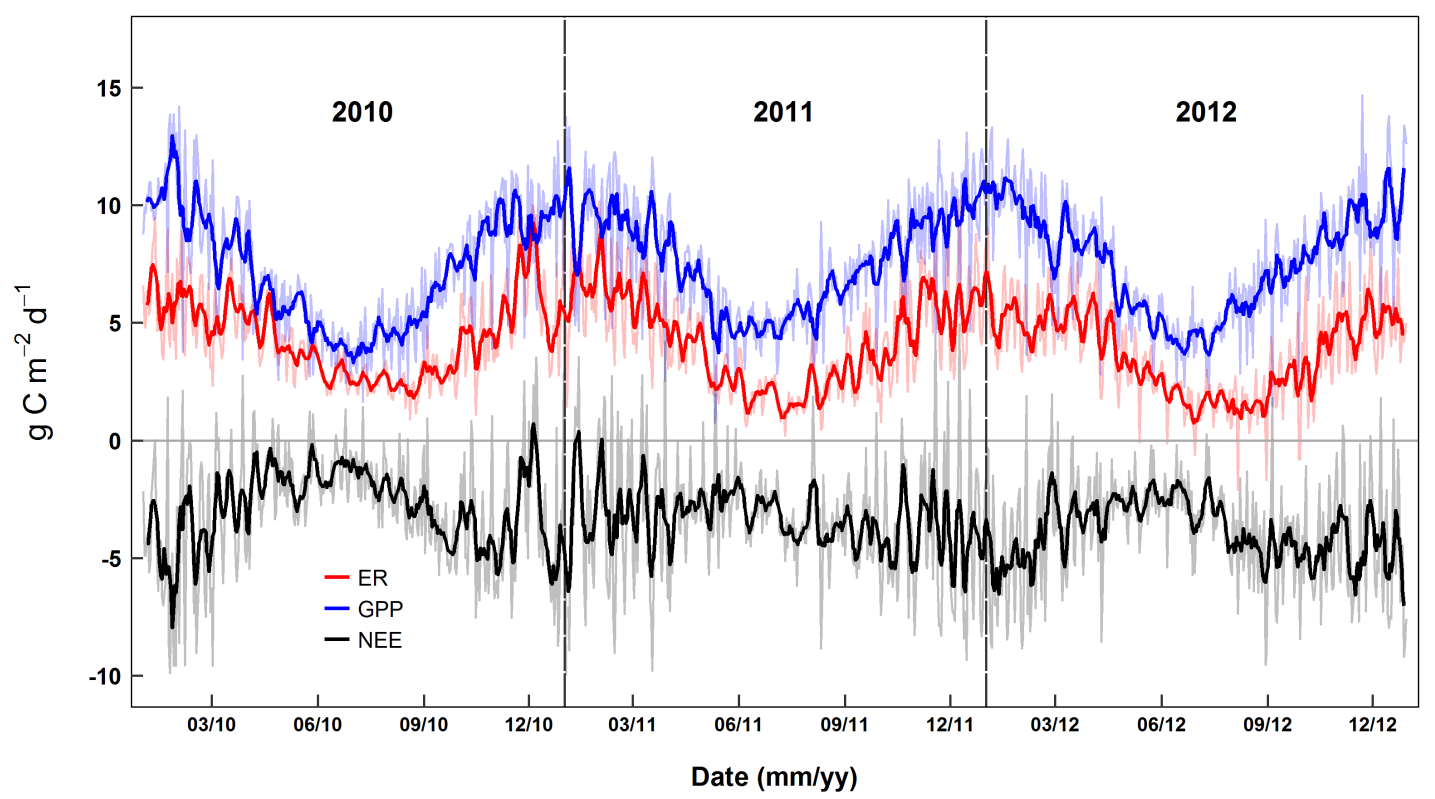

Figure 3. Ecosystem carbon fluxes of the Wombat State forest OzFlux site from 2010 to 2012: ecosystem respiration (ER, red lines), gross primary productivity (GPP, blue lines) and net ecosystem carbon exchange (NEE, black lines). Displayed is the output of the DINGO partitioning method (2a) using the night-time data approach with $\mathrm{NN}$ and early evening hours with daily totals $\left(\mathrm{g} \mathrm{C} \mathrm{m}^{-2} \mathrm{~d}^{-1}\right)$ of ecosystem carbon fluxes (shaded lines) and 7-day running means of daily totals (bold lines) for better illustration.

mum midday VPD of $3.41 \mathrm{kPa}$ was observed in January 2012 (Fig. 2d). Inter-annual variation in $F_{\text {sd }}, T_{\mathrm{a}}$ and $T_{\mathrm{s}}$ was marginal (Fig. 2b, c), while mean annual VPD was significantly $(p<0.001)$ higher in $2012(0.47 \mathrm{kPa})$ compared to 2010 and 2011 (0.36 and $0.32 \mathrm{kPa}$; Table 2).

\subsection{Seasonal and inter-annual variation in $\mathrm{CO}_{2}$ ecosystem fluxes}

A pronounced seasonal pattern was observed in ER $(\mathrm{CV}=39 \%)$ but less so in GPP $(\mathrm{CV}=27 \%)$ and NEE $(\mathrm{CV}=24 \%$; Figs. 2a, 3, 4).

In general, the forest showed near-continuous net carbon uptake (negative NEE) throughout the 3-year pe- riod, with the highest net uptake rates during summer and spring months (seasonal daily means of NEE: -4.07 and $-3.98 \mathrm{~g} \mathrm{C} \mathrm{m}^{-2} \mathrm{~d}^{-1}$ ) and the lowest rates during winter and autumn (seasonal daily mean NEE: -2.86 and $-2.62 \mathrm{~g} \mathrm{C} \mathrm{m}^{-2} \mathrm{~d}^{-1}$; Figs. 2a, 3). Only in December 2010 and January 2011, did NEE become distinctly positive (net carbon loss) for a short period ( 3 to 4 consecutive days) due to an increase in ER in December 2010 and a decrease in GPP in January 2011 (by 40\%) in response to considerably high rainfall and limited solar input. Seasonal variability in NEE was noticeably less pronounced in $2011(\mathrm{CV}=9 \%)$ than in $2010(p<0.001, \mathrm{CV}=38 \%)$ and $2012(p<0.001$, $\mathrm{CV}=21 \%$; Fig. 4a). Inter-annual variation in NEE was high 


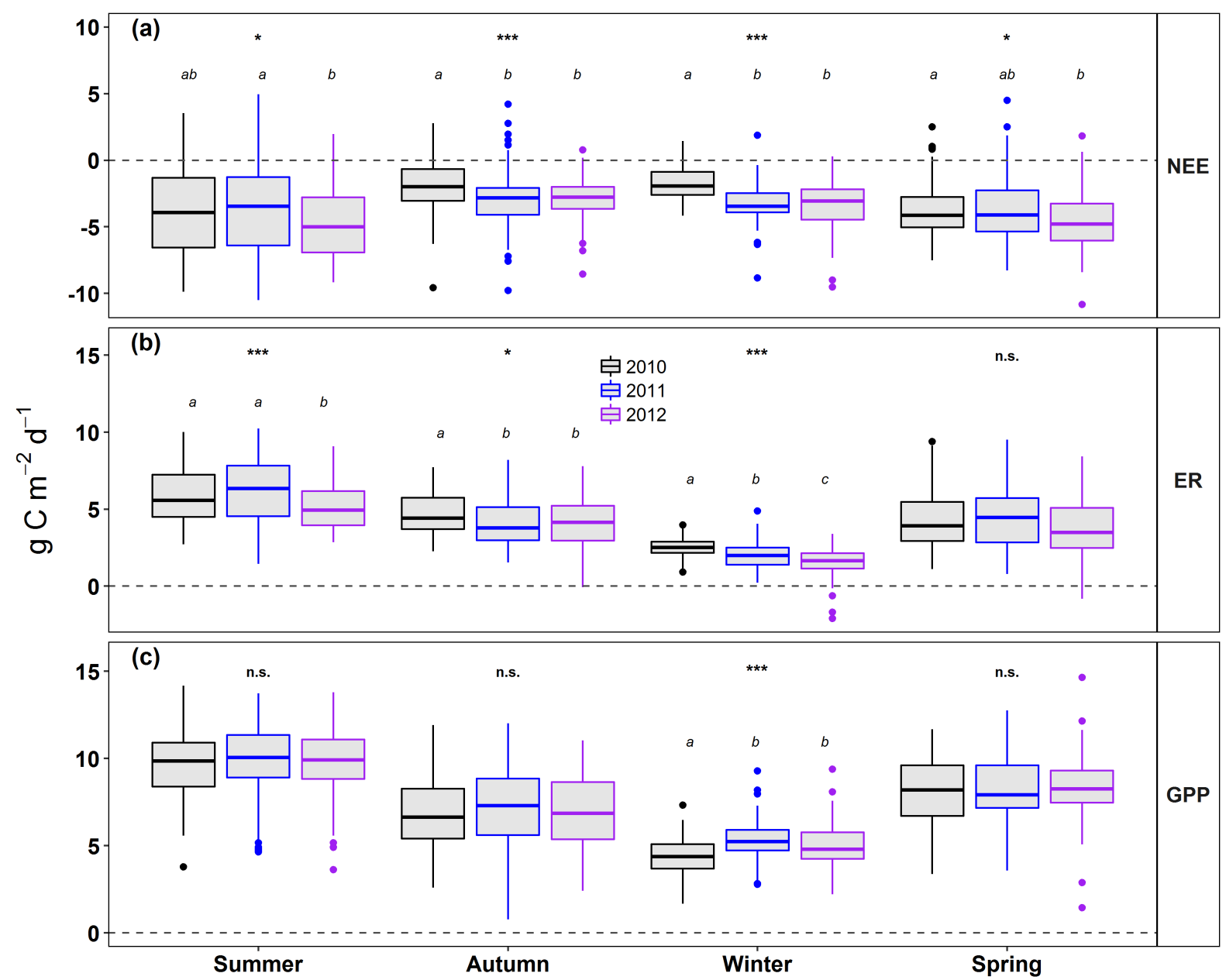

Figure 4. Box-and-whisker plots of daily averages of (a) NEE, (b) ER and (c) GPP for years and seasons; inter-annual differences are displayed for each season with $p$ values (significance level $p<0.05$ ); letters indicate year-to-year differences.

$(\mathrm{CV}=15 \%)$ and significant $(p<0.001)$ with most evident differences during winter and autumn (Table 2, Fig. 4a).

ER was greatest during summer (seasonal daily mean of $5.77 \mathrm{~g} \mathrm{C} \mathrm{m}^{-2} \mathrm{~d}^{-1}$ ), of similar magnitude in autumn and spring (4.34 and $4.23 \mathrm{~g} \mathrm{C} \mathrm{m}^{-2} \mathrm{~d}^{-1}$, respectively), and lowest during winter $\left(2.05 \mathrm{~g} \mathrm{C} \mathrm{m}^{-2} \mathrm{~d}^{-1}\right)$. Similar to NEE, GPP was greatest during summer (seasonal daily mean of $\left.9.85 \mathrm{~g} \mathrm{C} \mathrm{m}^{-2} \mathrm{~d}^{-1}\right)$, followed by spring $\left(8.20 \mathrm{~g} \mathrm{C} \mathrm{m}^{-2} \mathrm{~d}^{-1}\right)$, autumn $\left(6.96 \mathrm{~g} \mathrm{C} \mathrm{m}^{-2} \mathrm{~d}^{-1}\right)$, and winter $\left(4.91 \mathrm{~g} \mathrm{C} \mathrm{m}^{-2} \mathrm{~d}^{-1}\right)$.

Overall inter-annual variation in ER was moderate $(\mathrm{CV}=9 \%)$ and significant for all seasons except spring. ER was significantly lower in summer 2012 compared to the summer months in 2010 and 2011, as was winter 2012 compared to winters 2010 and 2011 (Fig. 4b). Overall, GPP estimates did not vary between years $(\mathrm{CV}<3 \%)$, and only in winter 2010 did GPP significantly differ from the winters of 2011 and 2012 (Fig. 4c). The ER / GPP ratio was highest during autumn and summer (0.62 and 0.59) and lowest during spring and winter (0.52 and 0.42$)$.

\subsection{Environmental drivers of $\mathrm{CO}_{2}$ ecosystem fluxes}

Results of the LRC fits and linear fits with $T_{\mathrm{a}}$ and VPD per year and season are presented in Table 3. Overall, $F_{\mathrm{sd}}$ explained $25 \%$ of the temporal variability in midday NEE (Fig. 5a), which did not considerably vary between observation years. Similarly, both $T_{\mathrm{a}}$ and VPD explained about 18 or $23 \%$ of the overall temporal variability in midday NEE (Fig. 5b, c), and again no considerable inter-annual differences were determined. However, a clear distinct seasonal pattern was shown in the dependence of midday NEE on $F_{\mathrm{sd}}$, $T_{\mathrm{a}}$ and VPD when coefficients of determinations were plotted for each month (Fig. 6a). While $F_{\text {sd }}$ was the dominant environmental driver during the mid- to late autumn and winter months $(36-47 \%$, mean $=42 \%), T_{\mathrm{a}}$ and VPD were the main controlling environmental variables during the spring, summer and early autumn months $\left(23-56 \%\right.$, mean $=40 \%$ for $T_{\mathrm{a}}$ and $15-48 \%$, mean $=31 \%$ for VPD). LRCs fitted for various $T_{\mathrm{a}}$ bins and VPD bins (Table 4) show a strong decrease in the net carbon uptake at temperatures above $20^{\circ} \mathrm{C}$ or VPD 

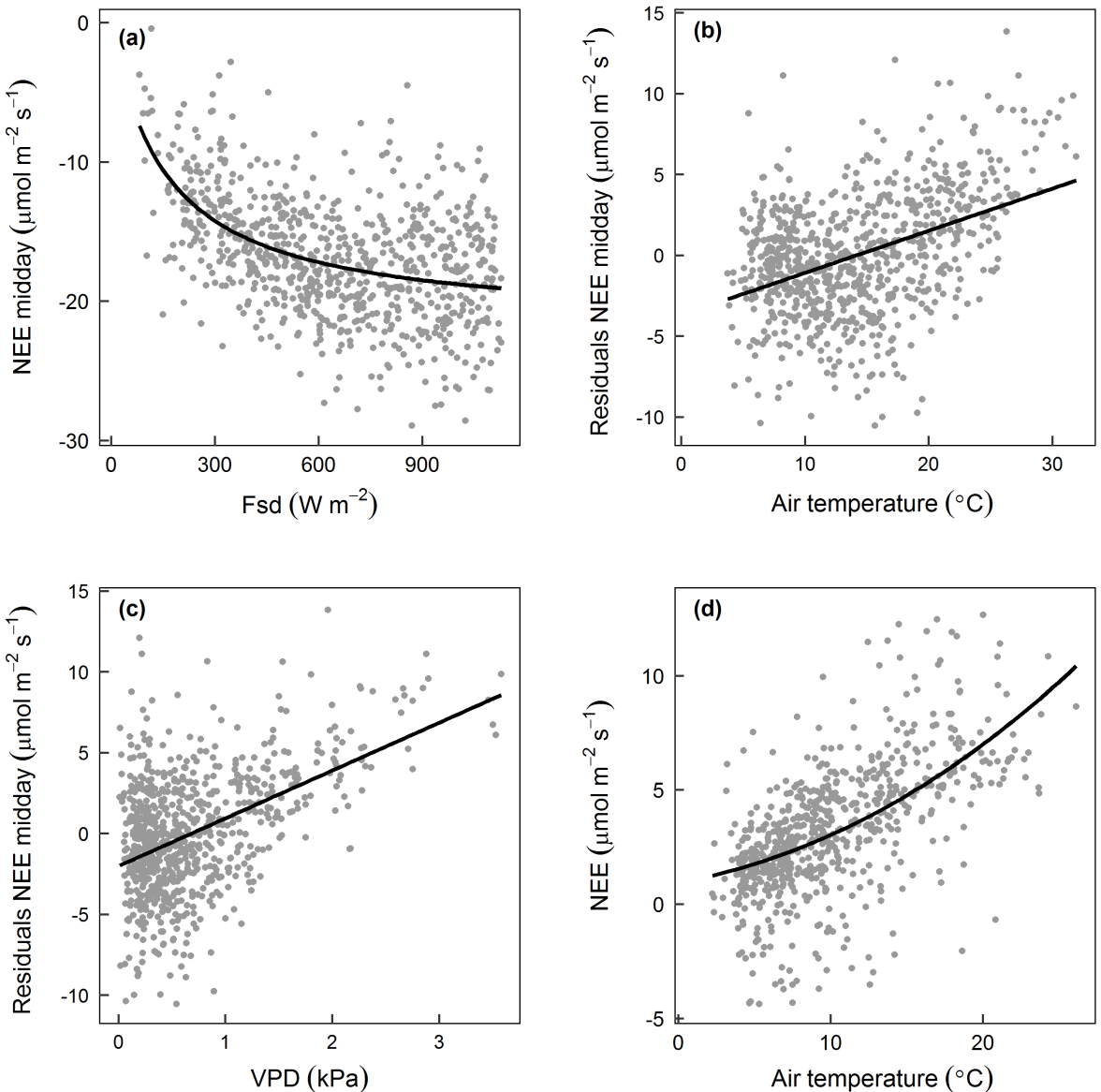

Figure 5. (a-c) Relationship between daily means of midday NEE and (a) incoming solar radiation $\left(F_{\text {sd }}\right)$ as a rectangular hyperbolic light-response curve (LRC), linear fits between residuals of LRC and (b) air temperature $\left(T_{\mathrm{a}}\right)$ or $(\mathbf{c})$ vapour pressure deficit (VPD). (d) Relationship between daily means of $u^{*}$-filtered night-time NEE and air temperature $\left(T_{\mathrm{a}}\right)$ as a temperature-response function after Lloyd and Taylor (1994); $R^{2}$ values are given in Tables 3 and 5.

Table 3. Parameters, standard errors and/or the coefficient of determination $\left(R^{2}\right)$ of (a) the rectangular hyperbolic light-response curve (LRC) between daily means of midday NEE and incoming radiation $\left(F_{\mathrm{sd}}\right)$, (b) linear fits between residuals of LRC and air temperature $\left(T_{\mathrm{a}}\right)$ or vapour pressure deficit (VPD), and (c) linear fits between second residuals (b) with $T_{\mathrm{a}}$ and soil water content (SWC) for subsets of data. $\alpha$ : initial slope of LRC and canopy light-utilization efficiency $\left(\mu \mathrm{mol} \mathrm{CO}_{2} \mathrm{~J}^{-1}\right) ; \beta$ : maximum NEE (i.e. uptake rate of the canopy) at light saturation $\left(\mu \mathrm{mol} \mathrm{CO} \mathrm{CO}_{2} \mathrm{~m}^{-2} \mathrm{~s}^{-1}\right)$. Significance level: ${ }^{* * *}<0.001,{ }^{* *}<0.01,{ }^{*}<0.5$; ns: not significant. nr: number of data points.

\begin{tabular}{lccc|cc|cc}
\hline \multirow{2}{*}{ Data subset } & \multicolumn{2}{c}{$(\mathbf{a}) F_{\mathrm{sd}}$} & & (b) $T_{\mathrm{a}}$ & $\mathrm{VPD}$ & (c) SWC & $\mathrm{nr}$ \\
\cline { 2 - 7 } & $\alpha(\mathrm{SE})$ & $\beta(\mathrm{SE})$ & $R^{2}$ & $R^{2}$ & $R^{2}$ & $R^{2}$ & \\
\hline All data & $-0.14(0.01)^{* * *}$ & $-21.8(0.0)^{* * *}$ & 0.25 & $0.18^{* * *}$ & $0.23^{* * *}$ & $0.05^{* * *}$ & 792 \\
2010 & $-0.11(0.02)^{* * *}$ & $-22.5(0.0)^{* * *}$ & 0.28 & $0.19^{* * *}$ & $0.25^{* * *}$ & $0.05^{* * *}$ & 213 \\
2011 & $-0.13(0.02)^{* * *}$ & $-21.9(0.0)^{* * *}$ & 0.27 & $0.21^{* * *}$ & $0.21^{* * *}$ & $0.10^{* * *}$ & 292 \\
2012 & $-0.17(0.02)^{* * *}$ & $-21.3(0.0)^{* * *}$ & 0.22 & $0.15^{* * *}$ & $0.24^{* * *}$ & $0.04^{* * *}$ & 287 \\
\hline
\end{tabular}

values above $1.2 \mathrm{kPa}$. A clear differentiation between $T_{\mathrm{a}}$ and VPD was very difficult because of the strong correlation between VPD and $T_{\mathrm{a}}$. While overall and inter-annual variability in residuals of midday NEE were marginally better explained by VPD than $T_{\mathrm{a}}$, variability in midday NEE residuals from spring to early autumn correlated more strongly with changes in $T_{\mathrm{a}}$ than VPD. No apparent influence of SWC on residuals of NEE or LRCs was determined (Tables 3c, 4).

Results of LT and linear fits with SWC per year and season are presented in Table 5. Overall, $36 \%$ of the temporal variability in $u^{*}$-filtered night-time NEE was explained by $T_{\mathrm{a}}$ (Fig. $5 \mathrm{~d}$ ), which varied from $30 \%$ in 2012 to $31 \%$ 

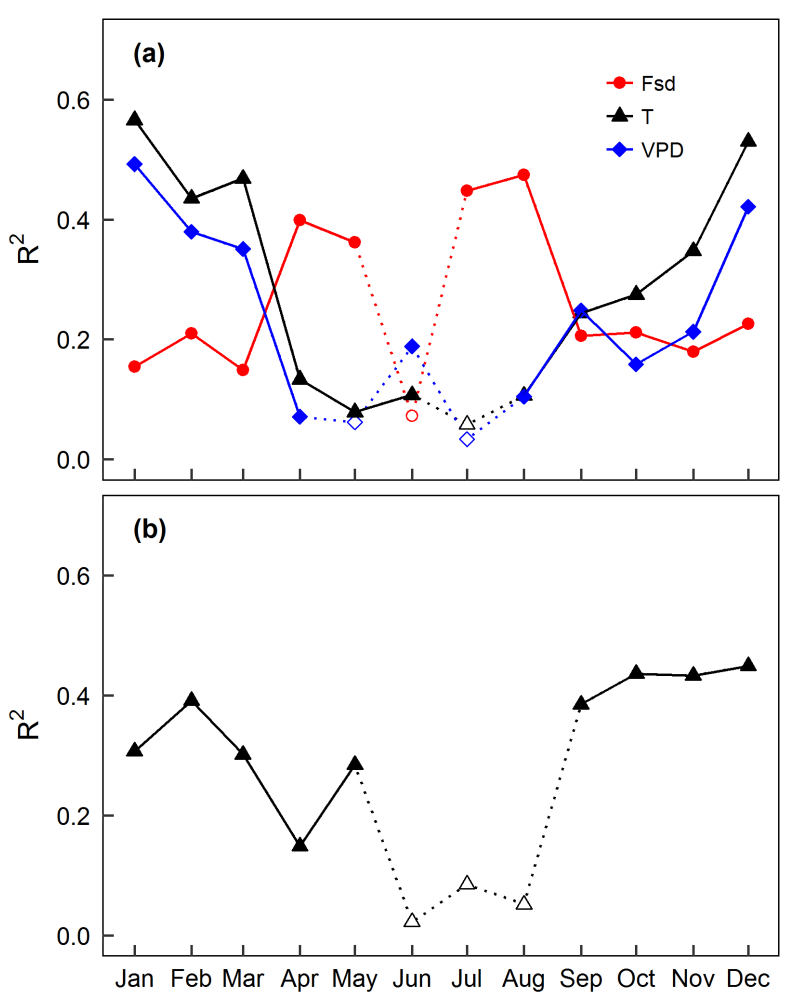

Figure 6. Seasonal variability in environmental controls of daytime and night-time NEE. Coefficients of determination $\left(R^{2}\right)$ of (a) the rectangular hyperbolic light-response curve (LRC) between daily means of midday NEE and incoming radiation $\left(F_{\mathrm{Sd}}\right.$; red lines and circles), linear fits between residuals of LRC and air temperature ( $T_{\mathrm{a}}$; black lines and triangles) or vapour pressure deficit (VPD; blue lines and diamonds) and (b) the temperature-response function after Lloyd and Taylor (1994) between daily means of $u^{*}$-filtered nighttime NEE and air temperature $\left(T_{\mathrm{a}}\right.$; black lines and triangles) per month pooled over 3 years. Open symbols indicate non-significant $R^{2}$ values; data points per month for panel (a) from January to December: $62,74,77,76,58,42,56,60,74,75,66,72$; data points per month for panel (b) from January to December: 55, 69, 63, 66, $52,45,41,57,63,63,52 ; 68$.

in 2010 and $49 \%$ in 2011. On seasonal timescales, the dependence of night-time NEE on $T_{\mathrm{a}}$ strongly varied, being greatest during spring $(39-44 \%$, mean $=42 \%)$ followed by summer $(31-45 \%$, mean $=38 \%)$ and lowest during autumn $(15-30 \%$, mean $=24 \%)$ (Fig. 6b). No significant relationships could be determined during winter months in which greater data gaps occurred compared to other months. Neither LT fitted for SWC bins (Table 5) nor linear relationships between SWC and LT residuals showed an influence of SWC on night-time NEE or its temperature sensitivity, with the exception of the winter month July when night-time NEE decreased with increasing SWC $\left(R^{2}=0.26^{* * *}\right)$.
Table 4. Parameters, standard errors and/or the coefficient of determination $\left(R^{2}\right)$ of the rectangular hyperbolic light-response curve (LRC) between daily means of midday NEE and incoming radiation $\left(F_{\text {sd }}\right)$ for various $T_{\mathrm{a}}$ bins, VPD bins and SWC bins. $\alpha$ : initial slope of LRC and canopy light-utilization efficiency $\left(\mu \mathrm{mol} \mathrm{CO}_{2} \mathrm{~J}^{-1}\right) ; \beta$ : maximum NEE (i.e. uptake rate of the canopy) at light saturation $\left(\mu \mathrm{mol} \mathrm{CO} 2 \mathrm{~m}^{-2} \mathrm{~s}^{-1}\right)$. Significance level: ${ }^{* *}<0.001$; ns: not significant. nr: number of data points.

\begin{tabular}{|c|c|c|c|c|}
\hline LRC & $\alpha(\mathrm{SE})$ & $\beta(\mathrm{SE})$ & $R^{2}$ & $\mathrm{nr}$ \\
\hline \multicolumn{5}{|l|}{$T_{\mathrm{a}}$ bins } \\
\hline$<8$ & $-0.14(0.02)^{* * *}$ & $-23.6(0.0)^{* * *}$ & 0.39 & 133 \\
\hline $8-12$ & $-0.09(0.01)^{* * *}$ & $-29.3(0.0)^{* * *}$ & 0.55 & 205 \\
\hline $12-16$ & $-0.07(0.01)^{* * *}$ & $-30.4(0.0)^{* * *}$ & 0.50 & 172 \\
\hline $16-20$ & $-0.07(0.01)^{* * *}$ & $-27.9(0.0)^{* * *}$ & 0.37 & 124 \\
\hline $20-24$ & $-0.08(0.02)^{* * *}$ & $-20.7(0.0)^{* * *}$ & 0.19 & 97 \\
\hline $24-28$ & $-0.06(0.03) \mathrm{ns}$ & $-20.5(0.1)^{* * *}$ & 0.13 & 49 \\
\hline \multicolumn{5}{|c|}{ VPD bins } \\
\hline$<0.4$ & $-0.10(0.01)^{* * *}$ & $-28.7(0.0)^{* * *}$ & 0.46 & 324 \\
\hline $0.4-0.8$ & $-0.07(0.01)^{* * *}$ & $-30.5(0.0) * * *$ & 0.44 & 232 \\
\hline $0.8-1.2$ & $-0.05(0.01)^{* * *}$ & $-32.9(0.0)^{* * *}$ & 0.47 & 103 \\
\hline $1.2-1.6$ & $-0.62(1.39) \mathrm{ns}$ & $-16.7(0.7)^{* * *}$ & 0.00 & 68 \\
\hline $1.6-2.0$ & $-0.16(0.25) \mathrm{ns}$ & $-16.3(0.5)^{* * *}$ & 0.02 & 25 \\
\hline $2.0-2.4$ & $-0.06(0.05) \mathrm{ns}$ & $-18.7(0.2)^{* * *}$ & 0.09 & 26 \\
\hline $2.4-2.8$ & $-0.05(0.03) \mathrm{ns}$ & $-15.1(0.2)^{* * *}$ & 0.47 & 7 \\
\hline $2.8-3.2$ & - & - & - & \\
\hline$>3.2$ & $-0.08(0.27) \mathrm{ns}$ & $-12.7(0.8)^{* * *}$ & 0.05 & 4 \\
\hline \multicolumn{5}{|c|}{ SWC bins } \\
\hline$<0.22$ & $-0.11(0.02)^{* * *}$ & $-22.35(0.0)^{* * *}$ & 0.18 & 258 \\
\hline$\geq 0.22$ & $-0.14(0.01)^{* * *}$ & $-21.88(0.0)^{* * *}$ & 0.29 & 534 \\
\hline
\end{tabular}

Table 5. Parameters, standard errors and/or the coefficient of determination $\left(R^{2}\right)$ of the temperature-response function after Lloyd and Taylor (1994) between daily means of $u^{*}$-filtered night-time NEE and air temperature $\left(T_{\mathrm{a}}\right)$ for subsets of data. $R_{\text {ref }}$ : basal respiration rate at $10^{\circ} \mathrm{C}\left(\mu \mathrm{mol} \mathrm{CO}_{2} \mathrm{~J}^{-1}\right) ; E$ : activation energy parameter. Significance level: ${ }^{* * *}<0.001,{ }^{* *}<0.01,{ }^{*}<0.5$; ns: not significant. nr: number of data points.

\begin{tabular}{lcccc}
\hline LT & $R_{\text {ref }}(\mathrm{SE})$ & $E(\mathrm{SE})$ & $R^{2}$ & $\mathrm{nr}$ \\
\hline All data & $3.0(0.1)^{* * *}$ & $310(16)^{* * *}$ & 0.36 & 694 \\
2010 & $3.6(0.2)^{* * *}$ & $215(23)^{* * *}$ & 0.31 & 214 \\
2011 & $2.8(0.2)^{* * *}$ & $405(27)^{* * *}$ & 0.49 & 234 \\
2012 & $2.8(0.2)^{* * *}$ & $306(31)^{* * *}$ & 0.30 & 246 \\
\hline SWC bins & & & & \\
\hline $0.1-<0.15$ & $2.1(0.5)^{* * *}$ & $349(94)^{* * *}$ & 0.34 & 37 \\
$0.15-<0.20$ & $3.0(0.3)^{* * *}$ & $285(44)^{* * *}$ & 0.27 & 138 \\
$0.20-<0.25$ & $3.1(0.2)^{* * *}$ & $339(34)^{* * *}$ & 0.38 & 146 \\
$0.25-<0.30$ & $3.4(0.2)^{* * *}$ & $337(30)^{* * *}$ & 0.38 & 200 \\
$>0.30$ & $3.3(0.2)^{* * *}$ & $527(40)^{* * *}$ & 0.42 & 173 \\
\hline
\end{tabular}




\subsection{Annual estimates of NEE, GPP, and ER and associated uncertainties}

From the various partitioning methods applied, the DINGO output with the night-time data approach using NN and $u^{*}$ filtered early evening hours resulted in ER estimates most consistent with the soil respiration data; in terms of the relative contribution of soil respiration, exceeding 1 was minimal (see Supplement Fig. S2a). However, the daytime approach partitioning method using the LRC with the DINGO routine (3a) (Fig. S3a) yielded similar results, followed by the night-time approach using the Lloyd and Taylor temperatureresponse function (1) in which night-time fluxes only were filtered after the $u^{*}$ threshold (Fig. S1c). Overall, the coefficient of variation in annual estimates of ER derived from different partitioning methods ranged from 8 to $10 \%$, while variation in annual estimates of NEE and GPP was small (47 and 2-4\%) (see Supplement Fig. S4, Table S2).

The forest was a considerable and continuous carbon sink during the 3-year study period, with a mean NEE of $-1234 \pm 109 \mathrm{~g} \mathrm{C} \mathrm{m}^{-2} \mathrm{yr}^{-1}$. Estimates of annual NEE increased from $-1046 \mathrm{~g} \mathrm{C} \mathrm{m}^{-2} \mathrm{yr}^{-1}$ in 2010 to $-1424 \mathrm{~g} \mathrm{C} \mathrm{m}^{-2} \mathrm{yr}^{-1}$ in 2012 (Table 2). Estimates for annual ER were similar for 2010 and 2011, whereas in 2012 annual ER decreased (Table 2). Annual GPP estimates were slightly higher in 2010 compared to other years and were similar for 2011 and 2012 (Table 2). ER was on average $55 \%$ of GPP, but this ranged between $61 \%$ (2010) and 49\% (2012) (Table 2).

\section{Discussion}

\subsection{Seasonal variability in $\mathrm{CO}_{2}$ ecosystem fluxes}

Gross and net $\mathrm{CO}_{2}$ ecosystem fluxes showed strong seasonality in this dry temperate eucalypt forest. On a seasonal timescale, GPP exceeded ER almost continually, even in winter; thus, NEE showed a net carbon uptake across all seasons. Daily minimum and maximum rates of ER and daily minimum rates of GPP were within the reported range for temperate evergreen coniferous and deciduous broadleaved forests compiled by Falge et al. (2002). Although daily maximum GPP rates at our forest site $\left(14.7 \mathrm{~g} \mathrm{C} \mathrm{m}^{-2} \mathrm{~d}^{-1}\right)$ were comparable with those from temperate evergreen coniferous forests (16.6-26.3 $\mathrm{g} \mathrm{C} \mathrm{m}^{-2} \mathrm{~d}^{-1}$ ), they were much lower than those reported for temperate deciduous broadleaved forests (22.4-31.0 $\mathrm{g} \mathrm{C} \mathrm{m}^{-2} \mathrm{~d}^{-1}$ ) during growing seasons (Falge et al., 2002).

Both GPP and ER peaked during summer and were lowest in winter, which is similarly typical for temperate evergreen coniferous forests (Baldocchi, 2008; Baldocchi and Valentini, 2004). However, during spring the increase in ER lagged behind that of GPP, an occurrence similarly typical for temperate deciduous broadleaved forests (Baldocchi, 2008;
Baldocchi and Valentini, 2004). Thus, NEE peaked in early spring and again in summer. A likely explanation for the delayed increase in ER as compared to GPP in springtime could be a limitation of microbial decomposition due to lower temperatures or substrate supply. Partitioning of soil respiration into its component fluxes of heterotrophic (microbial) and belowground autotrophic (plant) respiration in an earlier study (Hinko-Najera et al., 2015) showed that heterotrophic respiration was low during springtime but increased and peaked during (late) summer months corresponding to when total soil respiration fluxes were greatest (Fig. S2a). Similar seasonal variability in GPP and ER was observed in a wet temperate eucalypt forest; however, NEE peaked only during spring in this forest as GPP was limited by water availability during the dry summer period (Kilinc et al., 2013). These phenomena highlight that carbon exchange dynamics in this dry temperate eucalypt forest are different in their seasonal behaviour from temperate deciduous broadleaved or evergreen coniferous forests in the Northern Hemisphere (Baldocchi, 2008; Baldocchi and Valentini, 2004; Falge et al., 2002); thus, the latter should not be used as analogues.

\subsection{Environmental drivers of $\mathrm{CO}_{2}$ ecosystem fluxes}

As indicated above, the overall main environmental drivers of NEE were radiation and temperature. Temporal variability in daytime NEE was equally strongly influenced by radiation, temperature and/or VPD, which did not vary throughout the 3-year study period. Interestingly, a strong seasonal variability in environmental controls on NEE was revealed. While radiation was the dominant environmental driver of daytime NEE in mid to late autumn and winter, temperature was the main environmental control from spring to early autumn. In accordance with daytime NEE, temperature sensitivity of night-time NEE followed a distinct seasonal pattern, with greater influence of $T_{\mathrm{a}}$ on night-time NEE during spring and summer months. An indication of a limitation of respiration due to high water content in July is, however, precautious as data availability was lowest $(<50 \%)$ during this month.

Dry temperate eucalypt forests, like most of Australia's forests, are generally characterized by dry summer periods and are thus greatly influenced by changes in water availability (Haverd et al., 2013a). However, environmental drivers related to water availability such as VPD and SWC had either a small or no influence on daytime NEE fluxes during summer months and night-time NEE fluxes. Thus, there was no apparent water limitation on carbon dynamics during our study period in this forest. This is in contrast with findings from Keith et al. (2012), van Gorsel et al. (2013) and Kilinc et al. (2013) for wet temperate eucalypt forests. In all these studies ecosystem carbon fluxes were limited by VPD and/or SWC during dry summer months, with the greatest effects on daytime NEE rather than night-time NEE. However, this can be explained by the anomalously high rainfall at our forest site due to strong La Niña events from mid-2010 to early 
2011 and early 2012 (BoM, 2012) during most of the study period. The lack of SWC influence on carbon fluxes until the end of 2012 was also evident in concurrent studies on soil respiration dynamics at the same study site in which SWC did not decline below a certain threshold to limit soil respiration (Hinko-Najera et al., 2015).

\subsection{Annual carbon balance and uncertainties}

The dry temperate eucalypt forest was a very strong and continuous carbon sink for all 3 years. Our mean annual ER / GPP ratio $(\sim 0.55)$ was lower than the mean ER / GPP ratio of 0.76 for Australian ecosystems (Beringer et al., 2016), the 0.80 reported for temperate forests (Janssens et al., 2001; Luyssaert et al., 2007) and the 0.77 derived from a global database (Baldocchi, 2008). Moreover, our annual estimates for NEE are greater than published estimates for forest ecosystems around the globe collated by Baldocchi et al. (2001) or Luyssaert et al. (2007), and our annual estimates are at the upper end of the probability distribution for sites within the global FLUXNET network (Baldocchi, 2014).

That temperate eucalypt forests in Australia exhibit large carbon uptake has been shown in wet temperate eucalypt forests (>1000 mm annual rainfall) only recently. A tall oldgrowth $E$. regnans forest had an NEE of $-930 \mathrm{~g} \mathrm{C} \mathrm{m}^{-2} \mathrm{yr}^{-1}$ (Beringer et al., 2016). A wet temperate E. delegatensis forest near Tumbarumba (Keith et al., 2009, 2012; van Gorsel et al., 2013) was a strong sink of $\sim 900 \mathrm{~g} \mathrm{C} \mathrm{m}^{-2} \mathrm{yr}^{-1}$ during years with average annual rainfall $(\sim 1400 \mathrm{~mm})$, but this sink was reduced $\left(\sim 750 \mathrm{~g} \mathrm{C} \mathrm{m}^{-2} \mathrm{yr}^{-1}\right)$ during the aboveaverage rainfall $(\sim 2000-2200 \mathrm{~mm})$ years of 2010 and 2011 (van Gorsel et al., 2013). Overcast conditions and thus reduced incoming solar radiation explained this reduced sink (van Gorsel et al., 2013). However, NEE estimates we report for our study site are higher than those reported from the Tumbarumba eucalypt forest during the same years of aboveaverage rainfall. A possible explanation for the greater net carbon uptake estimates in our dry temperate eucalypt forest might be the higher leaf area index $(\sim 1.8)$ (Griebel et al., 2016; Moore, 2011) than in the wet temperate eucalypt forest $(\sim 1.4)$ near Tumbarumba, conferring a higher canopy photosynthetic capacity. Our study supports the conclusion of Keith et al. (2009) that temperate eucalypt forests have a high carbon uptake potential because they are evergreen, and as such photosynthetic carbon uptake can occur throughout the year when conditions are favourable. Indeed, a detailed study of stem and canopy growth dynamics at our study site demonstrated that the trees in fact grow all year, with canopy expansion observed mainly in summer and early autumn, and the stem growth mainly in spring and autumn, but also to a lesser degree in winter (Griebel et al., 2017). Another possible explanation for the higher net carbon uptake estimates at our study site is the absence of summer dry periods and a stimulation of growth due to the high rainfall. Prior to the period of high rainfall in 2010-2012, forests throughout tem- perate Australia experienced a decade-long drought that negatively affected NEE and net primary production (Haverd et al., 2013b). Keith et al. (2012) and Kilinc et al. (2013) also reported that drought conditions in the wet temperate eucalypt forest strongly reduced NEE by having a greater negative effect on GPP than ER. Therefore, it is likely that the onset of high rainfall in winter and early spring 2010 led to favourable conditions for growth and high carbon uptake given the opportunistic behaviour of eucalypts to changing environmental conditions (Jacobs, 1955; Keith, 1997).

However, the possibility of a remaining underestimation of ER cannot be excluded, although it can be accounted for during data processing and partitioning and by the addition of a storage term. We observed low night-time fluxes of NEE, and hence ER, which indicated a decoupling within the forest canopy and thus advection fluxes during night. Hence, it is possible that the high NEE values reported here are partly due to an underestimation of ER due to advection. However, such an error is likely to be a systematic one, meaning that an overestimation of NEE would have consistently occurred during the different measurement years and seasons. Results from a recent study to validate more recent annual NEE estimates with a biomass inventory (biomass increment and carbon content) indicated that the NEE estimates from the EC measurements were systematically $30 \%$ greater than the net primary production of the tree biomass from inventory methods (Bennett, 2016, unpublished data). It is a reasonable assumption that tree net primary production contributed the majority to NEE and as such the inventory data would be a confirmation that the flux tower underestimates ER, resulting in a greater NEE. However, the underestimation was indeed of a similar magnitude in each of the measurement years and confirmed the high carbon uptake rate of this dry temperate eucalypt forest when compared to other ecosystems.

Our data indicate that the main environmental controls for daytime NEE (radiation and temperature) and night-time NEE (temperature) did not vary between years. We observed moderate variations in NEE amongst the 3 years, with an increase in NEE from 2010 through to 2012. The high rainfall in late 2010 and early 2011 most likely led to favourable forest growth conditions throughout 2011 and a stronger increase in GPP rather than ER and thus an increase in NEE from 2010 to 2011, most evident in autumn and winter. This 2011 increase in NEE is in accordance with the observed 2011 global sink anomaly (Haverd et al., 2013a, 2016; Poulter et al., 2014), which has been mainly attributed to semi-arid ecosystems in Australia (Eamus and Cleverly, 2015; Haverd et al., 2013a). Hence, our results indicate that the global sink anomaly was not limited to only semi-arid ecosystems. The further increase in NEE from 2011 to 2012 was indicated by a reduction in ER as GPP remained steady. Rainfall was lower in 2012 as compared to the previous 2 years and thus soil water content decreased towards the end of 2012 (summer), likely influencing ER but not GPP. Given that ER is often dominated by soil respiration, this pattern is 
in agreement with findings on soil respiration patterns from concurrent studies in the same forest (Hinko-Najera et al., 2015) in which low soil water contents led to a decrease in soil respiration.

\section{Conclusion}

Temperate eucalypt forests are underrepresented in global assessments concerning terrestrial and/or forest carbon dynamics and productivity (Baldocchi, 2008; Falge et al., 2002; Luyssaert et al., 2007), and so far no data have been available on ecosystem carbon exchange dynamics from dry temperate eucalypt forests. This study shows that not only wet temperate eucalypt forests but also dry temperate eucalypt forests have a large carbon uptake potential, particularly during above-average rainfall, and thus adds further evidence that temperate eucalypt forests are strong carbon sinks during favourable conditions (Keith et al., 2009). Furthermore, carbon dynamics in this dry temperate eucalypt forest, similar to other temperate eucalypt forests, do differ in their seasonal behaviour compared to temperate evergreen coniferous and deciduous broadleaved counterpart forests in the Northern Hemisphere. The evergreen nature of the trees, coupled with mild winter temperatures, allow for the year-round physiological activity of eucalypts, which can lead to continuous growth throughout the year. When this is coupled with high rainfall in the warmer summer months, it can lead to very large carbon uptake. However, long-term measurements over multiple years are required to further evaluate the net carbon sink strength of dry temperate eucalypt forests, particularly in years with drought conditions, a scenario predicted to increase in occurrence and intensify in southeastern Australia (Christensen et al., 2013; CSIRO, 2012). Furthermore, studies using alternative approaches, for example independent upscaled ER estimates from component flux measurements (Keith et al., 2009; Lavigne et al., 1997; Law et al., 1999; Phillips et al., 2010; Speckman et al., 2015), are needed to account for underestimation in ER due to advection fluxes and to validate measurements from the EC flux tower.

Data availability. The OzFlux QA-QC data set presented in this paper is available from the OzFlux Data Portal (Arndt, 2013) and the DINGO data set presented in this paper is available on figshare (Beringer and Hinko-Najera, 2017).

\section{The Supplement related to this article is available online} at https://doi.org/10.5194/bg-14-3781-2017-supplement.

Author contributions. NHN, SKA, SJL and JB designed the experiment. Field work was primarily carried out by NHN with help from
IM and JB. Data preparation and analysis was primarily performed by NHN with contributions from PI, CE and IM (quality control), JB (DINGO), CE and EvG (partitioning), and JFE (analysis of environmental drivers). NHN prepared the paper with contributions from all co-authors.

Competing interests. The authors declare that they have no conflict of interest.

Special issue statement. This article is part of the special issue "OzFlux: a network for the study of ecosystem carbon and water dynamics across Australia and New Zealand". It is not associated with a conference.

Acknowledgements. The study was supported by funding from the Terrestrial Ecosystem Research Network (TERN) Australian Supersite Network, the TERN OzFlux Network, the Australian Research Council (ARC) grants LE0882936 and DP120101735, and the Victorian Department of Environment Land, Water and Planning Integrated Forest Ecosystem Research program. We would like to thank Julio Najera and Darren Hocking for site and instrument maintenance. Jason Beringer is funded under an ARC Future Fellowship (FT110100602).

Edited by: Mirco Migliavacca

Reviewed by: two anonymous referees

\section{References}

ABARES: Montreal Process Implementation Group for Australia and National Forest Inventory Steering Committee, Australia's State of the Forests Report 2013, Canberra, Australia, 464 pp., 2013.

Abramowitz, G.: Towards a benchmark for land surface models, Geophys. Res. Lett., 32, L22702, https://doi.org/10.1029/2005GL024419, 2005.

Ahlström, A., Raupach, M. R., Schurgers, G., Smith, B., Arneth, A., Jung, M., Reichstein, M., Canadell, J. G., Friedlingstein, P., Jain, A. K., Kato, E., Poulter, B., Sitch, S., Stocker, B. D., Viovy, N., Wang, Y. P., Wiltshire, A., Zaehle, S., and Zeng, N.: The dominant role of semi-arid ecosystems in the trend and variability of the land $\mathrm{CO}_{2}$ sink, Science, 348, 895-899, 2015.

Arndt, S.: Wombat State Forest OzFlux-tower site OzFlux: Australian and New Zealand Flux Research and Monitoring, available at: http://hdl.handle.net/102.100.100/14237 (last access: 5 May 2017), 2013.

Attiwill, P. M. and Adams, M. A.: Nutrient cycling in forests, New Phytol., 124, 561-582, 1993.

Aubinet, M., Feigenwinter, C., Heinesch, B., Laffineur, Q., Papale, D., Reichstein, M., Rinne, J., and Gorsel, E.: Nighttime Flux Correction, in: Eddy Covariance, edited by: Aubinet, M., Vesala, T., and Papale, D., Springer Atmospheric Sciences, Springer Netherlands, 133-157, https://doi.org/10.1007/978-94007-2351-1_5, 2012. 
Baldocchi, D.: Breathing of the terrestrial biosphere: lessons learned from a global network of carbon dioxide flux measurement systems, Aust. J. Bot., 56, 1-26, 2008.

Baldocchi, D.: Measuring fluxes of trace gases and energy between ecosystems and the atmosphere - the state and future of the eddy covariance method, Glob. Change Biol., 20, 3600-3609, 2014.

Baldocchi, D., Falge, E., Gu, L. H., Olson, R., Hollinger, D., Running, S., Anthoni, P., Bernhofer, C., Davis, K., Evans, R., Fuentes, J., Goldstein, A., Katul, G., Law, B., Lee, X. H., Malhi, Y., Meyers, T., Munger, W., Oechel, W., U, K. T. P., Pilegaard, K., Schmid, H. P., Valentini, R., Verma, S., Vesala, T., Wilson, K., and Wofsy, S.: FLUXNET: A new tool to study the temporal and spatial variability of ecosystem-scale carbon dioxide, water vapor, and energy flux densities, B. Am. Meteorol. Soc., 82, 2415-2434, 2001.

Baldocchi, D. D.: Assessing the eddy covariance technique for evaluating carbon dioxide exchange rates of ecosystems: past, present and future, Glob. Change Biol., 9, 479-492, 2003.

Baldocchi, D. D. and Valentini, R.: Geographic and temporal variation of carbon exchange by ecosystems and their sensitivity to environmental perturbations, in: The Global Carbon Cycle: Integrating Humans, Climate and the Natural World. Scope 62, edited by: Field, C. B. and Raupach, M. R., Island Press, Washington, USA, 2004.

Ballantyne, A. P., Alden, C. B., Miller, J. B., Tans, P. P., and White, J. W. C.: Increase in observed net carbon dioxide uptake by land and oceans during the past 50 years, Nature, 488, 70-73, 2012.

Barr, A. G., Richardson, A. D., Hollinger, D. Y., Papale, D., Arain, M. A., Black, T. A., Bohrer, G., Dragoni, D., Fischer, M. L., Gu, L., Law, B. E., Margolis, H. A., McCaughey, J. H., Munger, J. W., Oechel, W., and Schaeffer, K.: Use of change-point detection for friction-velocity threshold evaluation in eddy-covariance studies, Agr. Forest Meteorol., 171, 31-45, 2013.

Beringer, J. and Hinko-Najera, N.: bg_2016_192_dataset_WombatForest_DINGOoutput_2010_2012.csv, avaialble at: https://figshare.com/articles/bg_2016_192_dataset_ WombatForest_DINGOoutput_2010_2013_csv/5223940, last access: 21 July 2017.

Beringer, J., Hutley, L. B., Tapper, N. J., and Cernusak, L. A.: Savanna fires and their impact on net ecosystem productivity in North Australia, Glob. Change Biol., 13, 990-1004, 2007.

Beringer, J., Hutley, L. B., Abramson, D., Arndt, S. K., Briggs, P., Bristow, M., Canadell, J. G., Cernusak, L. A., Eamus, D., Edwards, A. C., Evans, B. J., Fest, B., Goergen, K., Grover, S. P., Hacker, J., Haverd, V., Kanniah, K., Livesley, S. J., Lynch, A., Maier, S., Moore, C., Raupach, M., Russell-Smith, J., Scheiter, S., Tapper, N. J., and Uotila, P.: Fire in Australian savannas: from leaf to landscape, Glob. Change Biol., 21, 62-81, 2015.

Beringer, J., Hutley, L. B., McHugh, I., Arndt, S. K., Campbell, D., Cleugh, H. A., Cleverly, J., Resco de Dios, V., Eamus, D., Evans, B., Ewenz, C., Grace, P., Griebel, A., Haverd, V., HinkoNajera, N., Huete, A., Isaac, P., Kanniah, K., Leuning, R., Liddell, M. J., Macfarlane, C., Meyer, W., Moore, C., Pendall, E., Phillips, A., Phillips, R. L., Prober, S. M., Restrepo-Coupe, N., Rutledge, S., Schroder, I., Silberstein, R., Southall, P., Yee, M. S., Tapper, N. J., van Gorsel, E., Vote, C., Walker, J., and Wardlaw, T.: An introduction to the Australian and New Zealand flux tower network - OzFlux, Biogeosciences, 13, 5895-5916, https://doi.org/10.5194/bg-13-5895-2016, 2016.
Beringer, J., McHugh, I., Hutley, L. B., Isaac, P., and Kljun, N.: Technical note: Dynamic INtegrated Gap-filling and partitioning for OzFlux (DINGO), Biogeosciences, 14, 1457-1460, https://doi.org/10.5194/bg-14-1457-2017, 2017.

BoM: Record-breaking La Niña events: An analysis of the La Niña life cycle and the impacts and significance of the 2010-11 and 2011-12 La Niña events in Australia, National Climate Centre, A. G., Melbourne, Australia, 2012.

Carrara, A., Janssens, I. A., Yuste, J. C., and Ceulemans, R.: Seasonal changes in photosynthesis, respiration and NEE of a mixed temperate forest, Agr. Forest Meteorol., 126, 15-31, 2004.

Chapin, F. S., Woodwell, G. M., Randerson, J. T., Rastetter, E. B., Lovett, G. M., Baldocchi, D. D., Clark, D. A., Harmon, M. E., Schimel, D. S., Valentini, R., Wirth, C., Aber, J. D., Cole, J. J., Goulden, M. L., Harden, J. W., Heimann, M., Howarth, R. W., Matson, P. A., McGuire, A. D., Melillo, J. M., Mooney, H. A., Neff, J. C., Houghton, R. A., Pace, M. L., Ryan, M. G., Running, S. W., Sala, O. E., Schlesinger, W. H., and Schulze, E. D.: Reconciling carbon-cycle concepts, terminology, and methods, Ecosystems, 9, 1041-1050, 2006.

Chen, J., Falk, M., Euskirchen, E., Paw U, K. T., Suchanek, T. H., Ustin, S. L., Bond, B. J., Brosofske, K. D., Phillips, N., and $\mathrm{Bi}, \mathrm{R}$. : Biophysical controls of carbon flows in three successional Douglas-fir stands based on eddy-covariance measurements, Tree Physiol., 22, 169-177, 2002.

Christensen, J. H., Krishna Kumar, K., Aldrian, E., An, S.-I., Cavalcanti, I. F. A., de Castro, M., Dong, W., Goswami, P., Hall, A., Kanyanga, J. K., Kitoh, A., Kossin, J., Lau, N.-C., Renwick, J., Stephenson, D. B., Xie, S.-P., and Zhou, T.: Climate Phenomena and their Relevance for Future Regional Climate Change, in: Climate Change 2013: The Physical Science Basis. Contribution of Working Group I to the Fifth Assessment Report of the Intergovernmental Panel on Climate Change, edited by: Stocker, T. F., Qin, D., Plattner, G.-K., Tignor, M., Allen, S. K., Boschung, J., Nauels, A., Xia, Y., Bex, V., and Midgley, P. M., Cambridge University Press, Cambridge, UK and New York, NY, USA, 2013.

Ciais, P., Reichstein, M., Viovy, N., Granier, A., Ogee, J., Allard, V., Aubinet, M., Buchmann, N., Bernhofer, C., Carrara, A., Chevallier, F., De Noblet, N., Friend, A. D., Friedlingstein, P., Grunwald, T., Heinesch, B., Keronen, P., Knohl, A., Krinner, G., Loustau, D., Manca, G., Matteucci, G., Miglietta, F., Ourcival, J. M., Papale, D., Pilegaard, K., Rambal, S., Seufert, G., Soussana, J. F., Sanz, M. J., Schulze, E. D., Vesala, T., and Valentini, R.: Europewide reduction in primary productivity caused by the heat and drought in 2003, Nature, 437, 529-533, 2005.

Ciais, P., Sabine, C., Bala, G., Bopp, L., Brovkin, V., Canadell, J., Chhabra, A., DeFries, R., Galloway, J., Heimann, M., Jones, C., Le Quéré, C., Myneni, R. B., Piao, S., and Thornton, P.: Carbon and Other Biogeochemical Cycles, in: Climate Change 2013: The Physical Science Basis. Contribution of Working Group I to the Fifth Assessment Report of the Intergovernmental Panel on Climate Change, edited by: Stocker, T. F., Qin, D., Plattner, G.K., Tignor, M., Allen, S. K., Boschung, J., Nauels, A., Xia, Y., Bex, V., and Midgley, P. M., Cambridge University Press, Cambridge, UK and New York, NY, USA, 2013.

Cleverly, J., Boulain, N., Villalobos-Vega, R., Grant, N., Faux, R., Wood, C., Cook, P. G., Yu, Q., Leigh, A., and Eamus, D.: Dynamics of component carbon fluxes in a semi-arid Acacia wood- 
land, central Australia, J. Geophys. Res.-Biogeo., 118, 11681185, 2013.

Cox, P. M., Betts, R. A., Jones, C. D., Spall, S. A., and Totterdell, I. J.: Acceleration of global warming due to carbon-cycle feedbacks in a coupled climate model, Nature, 408, 184-187, 2000.

CSIRO: Climate and water availability in south-eastern Australia: A synthesis of findings from Phase 2 of the South Eastern Australian Climate Initiative (SEACI), CSIRO, Australia, 41 pp., 2012.

Dee, D. P., Uppala, S. M., Simmons, A. J., Berrisford, P., Poli, P., Kobayashi, S., Andrae, U., Balmaseda, M. A., Balsamo, G., Bauer, P., Bechtold, P., Beljaars, A. C. M., van de Berg, L., Bidlot, J., Bormann, N., Delsol, C., Dragani, R., Fuentes, M., Geer, A. J., Haimberger, L., Healy, S. B., Hersbach, H., Hólm, E. V., Isaksen, L., Kållberg, P., Köhler, M., Matricardi, M., McNally, A. P., Monge-Sanz, B. M., Morcrette, J. J., Park, B. K., Peubey, C., de Rosnay, P., Tavolato, C., Thépaut, J. N., and Vitart, F.: The ERA-Interim reanalysis: configuration and performance of the data assimilation system, Q. J. Roy. Meteor. Soc., 137, 553-597, 2011.

DSE: Forest Explorer Online, Department of Sustainability and Environment, The State of Victoria, available at: http://nremap-sc. nre.vic.gov.au/MapShare.v2/imf.jsp?site=forestexplorer (last access: 13 July 2016), 2012.

Eamus, D. and Cleverly, J.: Australia's role in the 2011 global carbon sink anomaly, Australasian Science, 36, 18-19, 2015.

Eamus, D., Cleverly, J., Boulain, N., Grant, N., Faux, R., and Villalobos-Vega, R.: Carbon and water fluxes in an arid-zone Acacia savanna woodland: An analyses of seasonal patterns and responses to rainfall events, Agr. Forest Meteorol., 182, 225-238, 2013.

EddyPro: EddyPro ${ }^{\circledR}$ Software (Version 6.2) [Computer software]. LI-COR, Inc; Infrastructure for Measurements of the European Carbon Cycle consortium, Lincoln, NE, USA, 2016.

Falge, E., Baldocchi, D., Olson, R., Anthoni, P., Aubinet, M., Bernhofer, C., Burba, G., Ceulemans, R., Clement, R., Dolman, H., Granier, A., Gross, P., Grunwald, T., Hollinger, D., Jensen, N. O., Katul, G., Keronen, P., Kowalski, A., Lai, C. T., Law, B. E., Meyers, T., Moncrieff, H., Moors, E., Munger, J. W., Pilegaard, K., Rannik, U., Rebmann, C., Suyker, A., Tenhunen, J., Tu, K., Verma, S., Vesala, T., Wilson, K., and Wofsy, S.: Gap filling strategies for defensible annual sums of net ecosystem exchange, Agr. Forest Meteorol., 107, 43-69, 2001.

Falge, E., Baldocchi, D., Tenhunen, J., Aubinet, M., Bakwin, P., Berbigier, P., Bernhofer, C., Burba, G., Clement, R., Davis, K. J., Elbers, J. A., Goldstein, A. H., Grelle, A., Granier, A., Guomundsson, J., Hollinger, D., Kowalski, A. S., Katul, G., Law, B. E., Malhi, Y., Meyers, T., Monson, R. K., Munger, J. W., Oechel, W., Paw, K. T., Pilegaard, K., Rannik, U., Rebmann, C., Suyker, A., Valentini, R., Wilson, K., and Wofsy, S.: Seasonality of ecosystem respiration and gross primary production as derived from FLUXNET measurements, Agr. Forest Meteorol., 113, $53-$ 74, 2002.

Finnigan, J.: The storage term in eddy flux calculations, Agr. Forest Meteorol., 136, 108-113, 2006.

Flanagan, L. B., Wever, L. A., and Carlson, P. J.: Seasonal and interannual variation in carbon dioxide exchange and carbon balance in a northern temperate grassland, Glob. Change Biol., 8, 599$615,2002$.
Goulden, M. L., Munger, J. W., Fan, S. M., Daube, B. C., and Wofsy, S. C.: Measurements of carbon sequestration by long-term eddy covariance: Methods and a critical evaluation of accuracy, Glob. Change Biol., 2, 169-182, 1996.

Griebel, A., Bennett, L. T., Culvenor, D. S., Newnham, G. J., and Arndt, S. K.: Reliability and limitations of a novel terrestrial laser scanner for daily monitoring of forest canopy dynamics, Remote Sens. Environ., 166, 205-213, 2015.

Griebel, A., Bennett, L. T., Metzen, D., Cleverly, J., Burba, G., and Arndt, S. K.: Effects of inhomogeneities within the flux footprint on the interpretation of seasonal, annual, and interannual ecosystem carbon exchange, Agr. Forest Meteorol., 221, 50-60, 2016.

Griebel, A., Bennett, L. T., and Arndt, S. K.: Evergreen and ever growing - Stem and canopy growth dynamics of a temperate eucalypt forest, Forest Ecol. Manag., 389, 417-426, 2017.

Haverd, V., Raupach, M. R., Briggs, P. R., Canadell, J. G., Isaac, P., Pickett-Heaps, C., Roxburgh, S. H., van Gorsel, E., Viscarra Rossel, R. A., and Wang, Z.: Multiple observation types reduce uncertainty in Australia's terrestrial carbon and water cycles, Biogeosciences, 10, 2011-2040, https://doi.org/10.5194/bg-102011-2013, 2013a.

Haverd, V., Raupach, M. R., Briggs, P. R., J. G. Canadell., Davis, S. J., Law, R. M., Meyer, C. P., Peters, G. P., Pickett-Heaps, C., and Sherman, B.: The Australian terrestrial carbon budget, Biogeosciences, 10, 851-869, https://doi.org/10.5194/bg-10-851-2013, 2013b.

Haverd, V., Smith, B., and Trudinger, C.: Dryland vegetation response to wet episode, not inherent shift in sensitivity to rainfall, behind Australia's role in 2011 global carbon sink anomaly, Glob. Change Biol., 22, 2315-2316, https://doi.org/10.1111/gcb.13202, 2016.

Hinko-Najera, N., Fest, B., Livesley, S. J., and Arndt, S. K.: Reduced throughfall decreases autotrophic respiration, but not heterotrophic respiration in a dry temperate broadleaved evergreen forest, Agr. Forest Meteorol., 200, 66-77, 2015.

Hollinger, D. and Richardson, A.: Uncertainty in eddy covariance measurements and its application to physiological models, Tree Physiol., 25, 873-885, 2005.

Hsu, K.-L., Gupta, H. V., Gao, X., Sorooshian, S., and Imam, B.: Self-organizing linear output map (SOLO): An artificial neural network suitable for hydrologic modeling and analysis, Water Resour. Res., 38, 38-31-38-17, https://doi.org/10.1029/2001WR000795, 2002.

Huete, A., Didan, K., Miura, T., Rodriguez, E. P., Gao, X., and Ferreira, L. G.: Overview of the radiometric and biophysical performance of the MODIS vegetation indices, Remote Sens. Environ., 83, 195-213, 2002.

Hutley, L. B., Leuning, R., Beringer, J., and Cleugh, H. A.: The utility of the eddy covariance techniques as a tool in carbon accounting: Tropical savanna as a case study, Aust. J. Bot., 53, 663-675, 2005.

IPCC: Climate Change 2013: The Physical Science Basis. Contribution of Working Group I to the Fifth Assessment Report of the Intergovernmental Panel on Climate Change, edited by: Stocker, T. F., Qin, D., Plattner, G.-K., Tignor, M., Allen, S. K., Boschung, J., Nauels, A., Xia, Y., Bex, V., and Midgley, P. M., 1535, Cambridge University Press, Cambridge, UK and New York, NY, USA, 2013. 
Isaac, P., Cleverly, J., and McHugh, I.: OzFluxQC, CSIRO, TERN, available at: https://github.com/OzFlux/OzFluxQC (last access: 31 January 2017), 2016.

Isaac, P., Cleverly, J., McHugh, I., van Gorsel, E., Ewenz, C., and Beringer, J.: OzFlux data: network integration from collection to curation, Biogeosciences, 14, 2903-2928, https://doi.org/10.5194/bg-14-2903-2017, 2017.

Jacobs, M. R.: Growth habits of the eucalypts, Commonwealth Government, Canberra, Australia, 1955.

Janssens, I. A., Lankreijer, H., Matteucci, G., Kowalski, A. S., Buchmann, N., Epron, D., Pilegaard, K., Kutsch, W., Longdoz, B., Grunwald, T., Montagnani, L., Dore, S., Rebmann, C., Moors, E. J., Grelle, A., Rannik, U., Morgenstern, K., Oltchev, S., Clement, R., Gudmundsson, J., Minerbi, S., Berbigier, P., Ibrom, A., Moncrieff, J., Aubinet, M., Bernhofer, C., Jensen, N. O., Vesala, T., Granier, A., Schulze, E. D., Lindroth, A., Dolman, A. J., Jarvis, P. G., Ceulemans, R., and Valentini, R.: Productivity overshadows temperature in determining soil and ecosystem respiration across European forests, Glob. Change Biol., 7, 269278, 2001

Jung, M., Reichstein, M., Margolis, H. A., Cescatti, A., Richardson, A. D., Arain, M. A., Arneth, A., Bernhofer, C., Bonal, D., Chen, J. Q., Gianelle, D., Gobron, N., Kiely, G., Kutsch, W., Lasslop, G., Law, B. E., Lindroth, A., Merbold, L., Montagnani, L., Moors, E. J., Papale, D., Sottocornola, M., Vaccari, F., and Williams, C.: Global patterns of land-atmosphere fluxes of carbon dioxide, latent heat, and sensible heat derived from eddy covariance, satellite, and meteorological observations, J. Geophys. Res.-Biogeosciences, 116, G00J07, https://doi.org/10.1029/2010JG001566, 2011.

Keenan, T. F., Davidson, E., Moffat, A. M., Munger, W., and Richardson, A. D.: Using model-data fusion to interpret past trends, and quantify uncertainties in future projections, of terrestrial ecosystem carbon cycling, Glob. Change Biol., 18, 25552569, 2012.

Keith, H.: Nutrient cycling in eucalypt ecosystems, in: Eucalypt Ecology: individuals to ecosystems, edited by: Williams, J. E. and Woinarski, J. C. Z., Cambridge University Press, New York, USA, 1997.

Keith, H., Leuning, R., Jacobsen, K. L., Cleugh, H. A., van Gorsel, E., Raison, R. J., Medlyn, B. E., Winters, A., and Keitel, C.: Multiple measurements constrain estimates of net carbon exchange by a Eucalyptus forest, Agr. Forest Meteorol., 149, 535-558, 2009.

Keith, H., van Gorsel, E., Jacobsen, K. L., and Cleugh, H. A.: Dynamics of carbon exchange in a Eucalyptus forest in response to interacting disturbance factors, Agr. Forest Meteorol., 153, 67$81,2012$.

Kilinc, M., Beringer, J., Hutley, L. B., Haverd, V., and Tapper, N.: An analysis of the surface energy budget above the world's tallest angiosperm forest, Agr. Forest Meteorol., 166-167, 23-31, 2012.

Kilinc, M., Beringer, J., Hutley, L. B., Tapper, N. J., and McGuire, D. A.: Carbon and water exchange of the world's tallest angiosperm forest, Agr. Forest Meteorol., 182, 215-224, 2013.

Kljun, N., Calanca, P., Rotachhi, M. W., and Schmid, H. P.: A simple parameterisation for flux footprint predictions, Bound.-Lay. Meteorol., 112, 503-523, 2004.

Lasslop, G., Reichstein, M., Papale, D., Richardson, A. D., Arneth, A., Barr, A., Stoy, P., and Wohlfahrt, G.: Separation of net ecosystem exchange into assimilation and respiration using a light response curve approach: critical issues and global evaluation, Glob. Change Biol., 16, 187-208, 2010.

Lavigne, M. B., Ryan, M. G., Anderson, D. E., Baldocchi, D. D., Crill, P. M., Fitzjarrald, D. R., Goulden, M. L., Gower, S. T., Massheder, J. M., McCaughey, J. H., Rayment, M., and Striegl, R. G.: Comparing nocturnal eddy covariance measurements to estimates of ecosystem respiration made by scaling chamber measurements at six coniferous boreal sites, J. Geophys. Res.Atmos., 102, 28977-28985, 1997.

Law, B. E., Ryan, M. G., and Anthoni, P. M.: Seasonal and annual respiration of a ponderosa pine ecosystem, Glob. Change Biol., 5, 169-182, 1999

Lee, X., Finnigan, J., and Paw U, K.: Coordinate Systems and Flux Bias Error, in: Handbook of Micrometeorology, edited by: Lee, X., Massman, W., and Law, B., Atmospheric and Oceanographic Sciences Library, Springer Netherlands, 2005.

Le Quéré, C., Andres, R. J., Boden, T., Conway, T., Houghton, R. A., House, J. I., Marland, G., Peters, G. P., van der Werf, G. R., Ahlström, A., Andrew, R. M., Bopp, L., Canadell, J. G., Ciais, P., Doney, S. C., Enright, C., Friedlingstein, P., Huntingford, C., Jain, A. K., Jourdain, C., Kato, E., Keeling, R. F., Klein Goldewijk, K., Levis, S., Levy, P., Lomas, M., Poulter, B., Raupach, M. R., Schwinger, J., Sitch, S., Stocker, B. D., Viovy, N., Zaehle, S., and Zeng, N.: The global carbon budget 1959-2011, Earth Syst. Sci. Data, 5, 165-185, https://doi.org/10.5194/essd-5-1652013, 2013.

Le Quéré, C., Moriarty, R., Andrew, R. M., Canadell, J. G., Sitch, S., Korsbakken, J. I., Friedlingstein, P., Peters, G. P., Andres, R. J., Boden, T. A., Houghton, R. A., House, J. I., Keeling, R. F., Tans, P., Arneth, A., Bakker, D. C. E., Barbero, L., Bopp, L., Chang, J., Chevallier, F., Chini, L. P., Ciais, P., Fader, M., Feely, R. A., Gkritzalis, T., Harris, I., Hauck, J., Ilyina, T., Jain, A. K., Kato, E., Kitidis, V., Klein Goldewijk, K., Koven, C., Landschützer, P., Lauvset, S. K., Lefèvre, N., Lenton, A., Lima, I. D., Metzl, N., Millero, F., Munro, D. R., Murata, A., Nabel, J. E. M. S., Nakaoka, S., Nojiri, Y., O’Brien, K., Olsen, A., Ono, T., Pérez, F. F., Pfeil, B., Pierrot, D., Poulter, B., Rehder, G., Rödenbeck, C., Saito, S., Schuster, U., Schwinger, J., Séférian, R., Steinhoff, T., Stocker, B. D., Sutton, A. J., Takahashi, T., Tilbrook, B., van der Laan-Luijkx, I. T., van der Werf, G. R., van Heuven, S., Vandemark, D., Viovy, N., Wiltshire, A., Zaehle, S., and Zeng, N.: Global Carbon Budget 2015, Earth Syst. Sci. Data, 7, 349-396, https://doi.org/10.5194/essd-7-349-2015, 2015.

Leuning, R., Cleugh, H. A., Zegelin, S. J., and Hughes, D.: Carbon and water fluxes over a temperate Eucalyptus forest and a tropical wet/dry savanna in Australia: measurements and comparison with MODIS remote sensing estimates, Agr. Forest Meteorol., 129, 151-173, 2005.

Lloyd, J. and Taylor, J. A.: On the temperature dependence of soil respiration, Funct. Ecol., 8, 315-323, 1994.

Luyssaert, S., Inglima, I., Jung, M., Richardson, A. D., Reichstein, M., Papale, D., Piao, S. L., Schulzes, E. D., Wingate, L., Matteucci, G., Aragao, L., Aubinet, M., Beers, C., Bernhofer, C., Black, K. G., Bonal, D., Bonnefond, J. M., Chambers, J., Ciais, P., Cook, B., Davis, K. J., Dolman, A. J., Gielen, B., Goulden, M., Grace, J., Granier, A., Grelle, A., Griffis, T., Grunwald, T., Guidolotti, G., Hanson, P. J., Harding, R., Hollinger, D. Y., Hutyra, L. R., Kolar, P., Kruijt, B., Kutsch, W., Lagergren, F., 
Laurila, T., Law, B. E., Le Maire, G., Lindroth, A., Loustau, D., Malhi, Y., Mateus, J., Migliavacca, M., Misson, L., Montagnani, L., Moncrieff, J., Moors, E., Munger, J. W., Nikinmaa, E., Ollinger, S. V., Pita, G., Rebmann, C., Roupsard, O., Saigusa, N., Sanz, M. J., Seufert, G., Sierra, C., Smith, M. L., Tang, J., Valentini, R., Vesala, T., and Janssens, I. A.: $\mathrm{CO}_{2}$ balance of boreal, temperate, and tropical forests derived from a global database, Glob. Change Biol., 13, 2509-2537, 2007.

Massman, W. J.: A simple method for estimating frequency response corrections for eddy covariance systems, Agr. Forest Meteorol., 104, 185-198, 2000.

Massman, W. J.: Reply to comment by Rannik on "A simple method for estimating frequency response corrections for eddy covariance systems", Agr. Forest Meteorol., 107, 247-251, 2001.

McHugh, I. D., Beringer, J., Cunningham, S. C., Baker, P. J., Cavagnaro, T. R., Mac Nally, R., and Thompson, R. M.: Interactions between nocturnal turbulent flux, storage and advection at an “ideal" eucalypt woodland site, Biogeosciences, 14, 3027-3050, https://doi.org/10.5194/bg-14-3027-2017, 2017.

Michaelis, L. and Menten, M. L.: Die Kinetik der Invertinwirkung, Biochem. Z., 49, 333-369, 1913.

Moncrieff, J., Clement, R., Finnigan, J., and Meyers, T.: Averaging, Detrending, and Filtering of Eddy Covariance Time Series, in: Handbook of Micrometeorology: A Guide for Surface Flux Measurement and Analysis, edited by: Lee, X., Massman, W., and Law, B., Springer Netherlands, Dordrecht, the Netherlands, 2005.

Moore, C. E.: The surface water balance of the Wombat State Forest, Victoria: An estimation using Eddy Covariance and sap flow techniques, 2011, Honours Thesis, School of Geography and Envrionmental Science, Monash University, Melbourne, Australia, 104 pp., 2011.

Mystakidis, S., Davin, E. L., Gruber, N., and Seneviratne, S. I.: Constraining future terrestrial carbon cycle projections using observation-based water and carbon flux estimates, Glob. Change Biol., 22, 2198-2215, https://doi.org/10.1111/gcb.13217, 2016.

Pan, Y., Birdsey, R. A., Fang, J., Houghton, R., Kauppi, P. E., Kurz, W. A., Phillips, O. L., Shvidenko, A., Lewis, S. L., Canadell, J. G., Ciais, P., Jackson, R. B., Pacala, S. W., McGuire, A. D., Piao, S., Rautiainen, A., Sitch, S., and Hayes, D.: A Large and Persistent Carbon Sink in the World's Forests, Science, 333, 988 993, 2011.

Papale, D. and Valentini, A.: A new assessment of European forests carbon exchanges by eddy fluxes and artificial neural network spatialization, Glob. Change Biol., 9, 525-535, 2003.

Phillips, S. C., Varner, R. K., Frolking, S., Munger, J. W., Bubier, J. L., Wofsy, S. C., and Crill, P. M.: Interannual, seasonal, and diel variation in soil respiration relative to ecosystem respiration at a wetland to upland slope at Harvard Forest, J. Geophys. Res.Biogeo., 115, G02019, https://doi.org/10.1029/2008JG000858, 2010.

Poulter, B., Frank, D., Ciais, P., Myneni, R. B., Andela, N., Bi, J., Broquet, G., Canadell, J. G., Chevallier, F., Liu, Y. Y., Running, S. W., Sitch, S., and van der Werf, G. R.: Contribution of semiarid ecosystems to interannual variability of the global carbon cycle, Nature, 509, 600-603, 2014.

Poynter, M.: Collaborative forest management in Victoria's Wombat State Forest - will it serve the interests of the wider community?, Austral. For., 68, 192-201, 2005.
Raupach, M. R. R., Briggs, P. R., Haverd, V., King, E. A., Paget, M., and Trudinger, C. M.: Australian Water Availability Project (AWAP): CSIRO Marine and Atmospheric Research Component: Final Report for Phase 3, CAWCR Technical Report No. 013, CSIRO and Bureau of Meteorology, Canberra, Austarlia, 2009.

R Core Team: R: A language and environment for statistical computing, R Foundation for Statistical Computing, Vienna, Austria, available at: https://www.R-project.org/ (last access: 25 May 2017), 2016.

Reichstein, M., Falge, E., Baldocchi, D., Papale, D., Aubinet, M., Berbigier, P., Bernhofer, C., Buchmann, N., Gilmanov, T., Granier, A., Grunwald, T., Havrankova, K., Ilvesniemi, H., Janous, D., Knohl, A., Laurila, T., Lohila, A., Loustau, D., Matteucci, G., Meyers, T., Miglietta, F., Ourcival, J. M., Pumpanen, J., Rambal, S., Rotenberg, E., Sanz, M., Tenhunen, J., Seufert, G., Vaccari, F., Vesala, T., Yakir, D., and Valentini, R.: On the separation of net ecosystem exchange into assimilation and ecosystem respiration: review and improved algorithm, Glob. Change Biol., 11, 1424-1439, 2005.

Reichstein, M., Ciais, P., Papale, D., Valentini, R., Running, S., Viovy, N., Cramer, W., Granier, A., Ogee, J., Allard, V., Aubinet, M., Bernhofer, C., Buchmann, N., Carrara, A., Grunwald, T., Heimann, M., Heinesch, B., Knohl, A., Kutsch, W., Loustau, D., Manca, G., Matteucci, G., Miglietta, F., Ourcival, J. M., Pilegaard, K., Pumpanen, J., Rambal, S., Schaphoff, S., Seufert, G., Soussana, J. F., Sanz, M. J., Vesala, T., and Zhao, M.: Reduction of ecosystem productivity and respiration during the European summer 2003 climate anomaly: a joint flux tower, remote sensing and modelling analysis, Glob. Change Biol., 13, 634-651, 2007.

Reichstein, M., Bahn, M., Ciais, P., Frank, D., Mahecha, M. D., Seneviratne, S. I., Zscheischler, J., Beer, C., Buchmann, N., Frank, D. C., Papale, D., Rammig, A., Smith, P., Thonicke, K., van der Velde, M., Vicca, S., Walz, A., and Wattenbach, M.: Climate extremes and the carbon cycle, Nature, 500, 287-295, 2013.

Robinson, N., Rees, D., Reynard, K., MacEwan, R., Dahlhaus, P., Imhof, M., Boyle, G., and Baxter, N.: A land resource assessment of the Corangamite region, Bendigo, Department of Primary Industries, Victoria, 131 pp., available at: http://vro.agriculture.vic. gov.au/dpi/vro/coranregn.nsf/pages/soil_landform_map (last access: 23 February 2016), 2003.

Roxburgh, S. H., Barrett, D. J., Berry, S. L., Carter, J. O., Davies, I. D., Gifford, R. M., Kirschbaum, M. U. E., McBeth, B. P., Noble, I. R., Parton, W. G., Raupach, M. R., and Roderick, M. L.: A critical overview of model estimates of net primary productivity for the Australian continent, Funct. Plant Biol., 31, 1043-1059, 2004.

Schlesinger, W. H., Dietze, M. C., Jackson, R. B., Phillips, R. P., Rhoades, C. C., Rustad, L. E., and Vose, J. M.: Forest biogeochemistry in response to drought, Glob. Change Biol., 22, 23182328, https://doi.org/10.1111/gcb.13105, 2015.

Sitch, S., Friedlingstein, P., Gruber, N., Jones, S. D., MurrayTortarolo, G., Ahlström, A., Doney, S. C., Graven, H., Heinze, C., Huntingford, C., Levis, S., Levy, P. E., Lomas, M., Poulter, B., Viovy, N., Zaehle, S., Zeng, N., Arneth, A., Bonan, G., Bopp, L., Canadell, J. G., Chevallier, F., Ciais, P., Ellis, R., Gloor, M., Peylin, P., Piao, S. L., Le Quéré, C., Smith, B., Zhu, Z., and Myneni, R.: Recent trends and drivers of regional 
sources and sinks of carbon dioxide, Biogeosciences, 12, 653679, https://doi.org/10.5194/bg-12-653-2015, 2015.

Speckman, H. N., Frank, J. M., Bradford, J. B., Miles, B. L., Massman, W. J., Parton, W. J., and Ryan, M. G.: Forest ecosystem respiration estimated from eddy covariance and chamber measurements under high turbulence and substantial tree mortality from bark beetles, Glob. Change Biol., 21, 708-721, 2015.

Tolhurst, K.: Effects of repeated low-intensity fires on the understorey of a mixed eucalypt foothill forest in south-eastern Australia. Fire Research Report No. 58. Fire Management, Department of Sustainability and Environment, East Melbourne, Victoria, Australia, 2003.

Valentini, R., Matteucci, G., Dolman, A. J., Schulze, E. D., Rebmann, C., Moors, E. J., Granier, A., Gross, P., Jensen, N. O., Pilegaard, K., Lindroth, A., Grelle, A., Bernhofer, C., Grunwald, T., Aubinet, M., Ceulemans, R., Kowalski, A. S., Vesala, T., Rannik, U., Berbigier, P., Loustau, D., Guomundsson, J., Thorgeirsson, H., Ibrom, A., Morgenstern, K., Clement, R., Moncrieff, J., Montagnani, L., Minerbi, S., and Jarvis, P. G.: Respiration as the main determinant of carbon balance in European forests, Nature, 404, 861-865, 2000.

van Gorsel, E., Leuning, R., Cleugh, H. A., Keith, H., and Suni, T.: Nocturnal carbon efflux: reconciliation of eddy covariance and chamber measurements using an alternative to the $u\left({ }^{*}\right)$-threshold filtering technique, Tellus B, 59, 397-403, 2007.

van Gorsel, E., Leuning, R., Cleugh, H. A., Keith, H., Kirschbaum, M. U. F., and Suni, T.: Application of an alternative method to derive reliable estimates of nighttime respiration from eddy covariance measurements in moderately complex topography, Agr. Forest Meteorol., 148, 1174-1180, 2008. van Gorsel, E., Berni, J. A. J., Briggs, P., Cabello-Leblic, A., Chasmer, L., Cleugh, H. A., Hacker, J., Hantson, S., Haverd, V., Hughes, D., Hopkinson, C., Keith, H., Kljun, N., Leuning, R., Yebra, M., and Zegelin, S.: Primary and secondary effects of climate variability on net ecosystem carbon exchange in an evergreen Eucalyptus forest, Agr. Forest Meteorol., 182-183, 248256, https://doi.org/10.1016/j.agrformet.2013.04.027, 2013.

Webb, E. K., Pearman, G. I., and Leuning, R.: Correction of flux measurements for density effects due to heat and water vapor transfer, Q. J. Roy. Meteor. Soc., 106, 85-100, 1980.

Whitehead, D. and Beadle, C. L.: Physiological regulation of productivity and water use in Eucalyptus: a review, Forest Ecol. Manag., 193, 113-140, 2004.

Wilczak, J. M., Oncley, S. P., and Stage, S. A.: Sonic Anemometer Tilt Correction Algorithms, Bound.-Lay. Meteorol., 99, 127150, 2001.

Yi, C., Ricciuto, D., Li, R., Wolbeck, J., Xu, X., Nilsson, M., Aires, L., Albertson, J. D., Ammann, C., and Arain, M. A.: Climate control of terrestrial carbon exchange across biomes and continents, Environ. Res. Lett., 5, 034007, https://doi.org/10.1088/17489326/5/3/034007, 2010.

Zhao, M. and Running, S. W.: Drought-Induced Reduction in Global Terrestrial Net Primary Production from 2000 Through 2009, Science, 329, 940-943, 2010. 